\title{
Association between Transfusion Status and Overall Survival in Patients with Myelodysplastic Syndromes: A Systematic Literature Review and Meta-Analysis
}

\author{
Sue Harnan ${ }^{a}$ Shiji Ren ${ }^{a}$ Tim Gomersall ${ }^{a}$ Emma S. Everson-Hock ${ }^{a}$ \\ Anthea Sutton $^{\text {a Sujith Dhanasiri }}{ }^{b}$ Austin Kulasekararaj ${ }^{c}$ \\ ${ }^{a}$ Health Economics and Decision Science, School of Health and Related Research, University of Sheffield, Sheffield, \\ ${ }^{b}$ Celgene Ltd., Uxbridge, and 'King's College Hospital, London, UK
}

\section{Key Words}

Myelodysplastic syndrome · Transfusion dependence •

Overall survival

\begin{abstract}
Introduction: Multiple studies show that transfusion independence (TI) in myelodysplastic syndrome (MDS) has a positive impact on overall survival (OS). To assess this, a systematic review and meta-analysis of the association between $\mathrm{TI}$ and OS in patients with MDS was conducted (PROSPERO ID: CRD42014007264). Methods: Comprehensive searches of 5 key bibliographic databases were conducted and supplemented with additional search techniques. Included were studies that had recruited adults aged $>18$ years with MDS and had examined the impact of transfusion status on OS. Results: Fifty-five studies (89 citations) were included. The vast majority reported a statistically significant hazard ratio (HR) for OS in favor of TI patients or in patients who acquired $\mathrm{Tl}$ after treatment. A random-effects meta-analysis was conducted. Patients classed as TI at baseline showed a 59\% decrease in the risk of death compared with transfusion-de-
\end{abstract}

pendent (TD) patients [HR 0.41; 95\% credible interval (Crl) 0.29-0.56], and this effect did not appear to interact significantly with illness severity (interaction coefficient HR 1.38; 95\% Crl 0.62-3.41). A meta-analysis of studies where patients acquired TI was not possible, but those studies consistently reported a survival benefit for those who acquired TI. Conclusion: The findings revealed a 59\% pooled reduction in mortality among TI patients when compared with TD patients.

(c) 2016 S. Karger AG, Base

\section{Introduction}

Primary myelodysplastic syndromes (MDS) are heterogeneous clonal disorders characterized by bone marrow failure manifesting as cytopenia(s) and a varying propensity for transformation into acute myeloid leukemia (AML). The prognostic importance of anemia and subsequent transfusion status in patients with MDS has been recognized. In 2007, Malcovati et al. [1] proposed the World Health Organization (WHO) classification-based

\section{KARGER}

E-Mail karger@karger.com

www.karger.com/aha
(C) 2016 S. Karger AG, Basel

0001-5792/16/1361-0023\$39.50/0
Sue Harnan

School of Health and Related Research, University of Sheffield

Regent Court, 30 Regent Street

Sheffield S1 4DA (UK)

E-Mail s.harnan@sheffield.ac.uk 
Prognostic Scoring System which replaced the International Prognostic Scoring System (IPSS) cytopenia category with transfusion dependence (TD). The depth of anemia correlates with TD and poor outcomes in MDS [2]. The precise reasons for the impact of transfusion status remain unclear, although it may be an indicator of underlying disease severity [3] and transfusions may lead to iron overload, which can cause organ dysfunction and death $[4,5]$.

Although the prognostic significance of TD is widely acknowledged, no systematic review has assessed the impact of transfusion status on overall survival (OS) in patients with MDS. It is also unclear whether the association varies according to illness severity (although isolated studies have provided some analysis of this) [6-9] and whether it holds for patients who achieve transfusion independence (TI) through treatment.

This study aimed to conduct a systematic review and meta-analysis of the association between OS and TI in patients with MDS. It further aimed to assess whether the association is modified by patient risk category and to assess the association in those who acquired TI through treatment.

\section{Methods}

The systematic review followed the principles recommended in the PRISMA statement [10]. The protocol is published in the PROSPERO database (http://www.crd.york.ac.uk/PROSPERO; record CRD42014007264).

Searches

Comprehensive electronic searches were conducted in 5 key bibliographic databases (MEDLINE, EMBASE, Cochrane Library, CINAHL and Science Citation Index), from inception to January 3, 2014, and updated in MEDLINE only on May 7, 2014. Sensitive key word strategies using free text and thesaurus terms were developed. Boolean operators and database-specific syntax were used to combine synonyms related to MDS and TD. Terms related to survival outcomes were not used because a scoping search found these were too restrictive due to a lack of survival outcome reporting in abstracts. Searches were limited to human studies only. An example of the search strategy used (from MEDLINE) is available as an online supplementary appendix (for all online suppl. material, see www. karger.com/doi/10.1159/000445163). Relevant conference proceedings were searched electronically, experts were contacted for additional studies, grey literature (guidelines and unpublished and unindexed studies) was searched online and the reference lists of relevant reviews and guidelines were checked to ensure data saturation.

\section{Study Selection}

Studies were included if they had recruited adults aged $>18$ years with a confirmed diagnosis of MDS and had reported OS for TI patients versus TD patients. Studies recruiting $>20 \%$ pediatric or primary AML patients were excluded. Studies were not excluded on the basis of changes in MDS definitions. Studies with any proportion of patients with AML secondary to MDS were included. Studies recruiting any patients with conditions other than these were excluded. Transfusion status expressed (or calculable) as units transfused per unit time was acceptable; however, total units transfused was not acceptable because this is not an indicator of degree of dependence. Studies comparing patients who acquired TI (e.g. through treatment) with those who did not were included but analyzed separately. Any expression of OS was acceptable, although only hazard ratios (HRs) were included in the meta-analysis. Studies only reporting predicted survival, progression-free survival or composite outcomes such as 'survival or progression to AML' were excluded. Studies with a follow-up of $<6$ months were excluded because short follow-ups may miss the effects of transfusion status. Studies with unclear follow-up length were included to avoid excluding potentially relevant studies on the basis of poor reporting. Randomized controlled trials (RCTs), cohort studies, consecutive case series of $\geq 10$ cases, before-after studies and casecontrol studies were included. Non-English-language studies were included if an English-language abstract described the study type, population and outcome in sufficient detail.

\section{Data Extraction}

A standardized data extraction form was developed following the recommendations in the Centre for Reviews and Dissemination Handbook [11] and piloted on studies of different designs. Data were extracted by one reviewer and checked by another. Disagreements were resolved through discussion or the involvement of a third reviewer.

\section{Quality Assessment}

Study quality was assessed using the validated Quality in Prognosis Studies (QUIPS) tool [12] adapted for this review. All items were included and scored as low risk, high risk or unclear risk (moderate and unclear risk as defined in the QUIPS guidelines). These included the assessment of: representativeness of study sample (selection bias), difference in key patient characteristics between those excluded or lost and those included (attrition bias), differences in TD measurement in those who survived versus those who did not (prognostic factor measurement bias), differences in OS measurement in TD versus TI patients (detection bias), how potential confounders were dealt with (confounding) and appropriateness of the statistical analysis (statistical analysis and reporting bias). Potential confounders of highest priority were IPSS or cytogenetics, WHO stage and age. Studies were scored for confounding according to whether some (unclear risk), all (low risk) or none (high risk) of these characteristics were accounted for in the analysis. For the statistical analysis item, studies were scored as 'unclear' when the Kaplan-Meier curves or multiple Cox regression analyses were not conducted or as 'high risk' when neither was conducted.

\section{Narrative Synthesis}

A narrative synthesis, including the tabulation of results and a consideration of clinically meaningful patterns, was conducted. Data were grouped by risk category of included patients and study type. Cohorts were classed as 'high risk' if inclusion was restricted to IPSS int-2 [13], patients with high-risk disease or those in WHO MDS subgroups [14] with excess blasts. Conversely, low-risk co- 
horts comprised studies that restricted inclusion in the IPSS lowor int-1-risk categories or WHO MDS subgroups without excess blasts. When both classifications were reported, the IPSS was preferred. Cohorts including both patients with high- and low-risk disease were classed as 'unselected'.

\section{Meta-Analysis}

Meta-analyses were conducted for studies that presented HRs. A Bayesian Markov chain Monte Carlo approach was conducted in WinBUGS, with a random-effects model to allow heterogeneity in the effect of TI on OS across studies. When HRs were expressed for TD rather than TI, the ratio was converted by dividing 1 by the reported HR.

Multiple Cox regression analyses were selected when presented because these corrected for confounding variables. To avoid double counting, only nonoverlapping cohort studies were included. When studies overlapped each other, 1 study was selected for inclusion in the meta-analysis by excluding studies with the narrowest patient spectrum (e.g. studies that only recruited patients who had an allogeneic stem cell transplant), studies with less adequate covariate adjustments in the multiple Cox regression analysis (see the definition in the Quality Assessment section), studies in which another study included additional patients (e.g. 2 extra years of data or abstracts when a full journal article was available) and studies lacking the recruitment date or location information which prevented an assessment of overlap. For studies with an unreported standard error, 95\% confidence interval (CI) or exact $p$ value (e.g. only reported $\mathrm{p}<0.001$ ), the $\mathrm{p}$ value was treated as the exact $\mathrm{p}$ value in the analysis (e.g. $\mathrm{p}=0.001$ when $\mathrm{p}<0.001$ was reported).

Sensitivity analyses were conducted which included univariate Cox regression analyses when multiple Cox regression analyses were not presented and included studies that only reported $\mathrm{Ka}$ plan-Meier curves. For the latter, Kaplan-Meier curves were digitized and patient-level data were reconstructed using the approach published in Guyot et al. [15] to obtain the estimated HR. A metaregression was conducted to investigate whether the effect of TI on OS differed according to patient risk category.

\section{Results}

The total number of unique records considered for inclusion was 1,842 (fig. 1). Of these, 1,641 were identified through electronic searching, 80 of which were included in the review. Expert sources and chance find articles contributed 4 additional articles. The reference lists of 45 reviews were checked for titles not retrieved by electronic searches, and 186 additional unique titles were considered for inclusion. Of these, 5 met the inclusion criteria and were selected for the review. No further unique titles were identified from the final reviews checked, thus achieving data saturation. In total, 89 articles were included in the review, representing 55 separate but often overlapping data sets. All studies and their parallel publications (in which no unique patients were analyzed) are listed in table 1.

Transfusion Independence and OS in Patients with MDS

\section{Risk of Bias}

Measurement of TD and OS was consistent in most studies, and statistical analyses were appropriate in most cases (i.e. log-rank test in univariate analyses, with multiple Cox regression models for $>1$ covariate; fig. 2). There was a low risk of attrition bias in approximately $50 \%$ of the studies, with unclear reporting of attrition being a common issue. Many studies exhibited issues with cohort representativeness (e.g. studies only including participants with available bone marrow biopsies) and covariate adjustment. A diagrammatic representation of the risk of bias assessment for each study is included in the online appendix (online suppl. fig. 1).

\section{Narrative Synthesis}

Three main study types were identified: (A) studies that recruited both TD and TI patients at baseline and compared OS between these 2 groups (generally retrospective cohort studies), (B) studies that recruited only TD patients and compared the OS of those who became TI after treatment with those who remained TD (generally RCTs) and (C) studies that recruited only TD patients at baseline and compared the OS of those with a high transfusion burden with those with a low transfusion burden (generally retrospective cohort studies; the same cutoff point was sometimes used to categorize patients as low burden in these studies as was used to categorize TI in the type A studies, but patients with no transfusions were missing). Most data sets $(n=43$, reported across 70 publications) were type A, 4 were type B (reported across 9 publications) and 5 were type $\mathrm{C}$ (table 1 ). Three studies were not study type A, B or C: Rojas et al. [16] recruited all TI patients at baseline and compared OS in those who became TD with those who did not and both Jädersten et al. [17] and List et al. [18] analyzed transfusion status as a continuous variable.

The studies were conducted in different countries and settings, most commonly in the USA, followed by Italy and Germany. Several included patients from $>1$ country or center. Most $(n=36)$ did not select patients on the basis of risk (unselected cohorts), although 16 were conducted with patients with low-risk disease only and 3 with high-risk disease only. Two unselected cohorts $[6,19]$ reported a low-risk subgroup analysis, and 1 study [9] reported both high- and low-risk subgroup analyses in separate publications $[7,8]$. The risk group was unclear in 1 study and was categorized as unselected [20]. Study cohort size ranged from 37 [21] to 9,820 [22]. However, the total number of patients included in the review is unclear because multiple studies drew patients from the same 


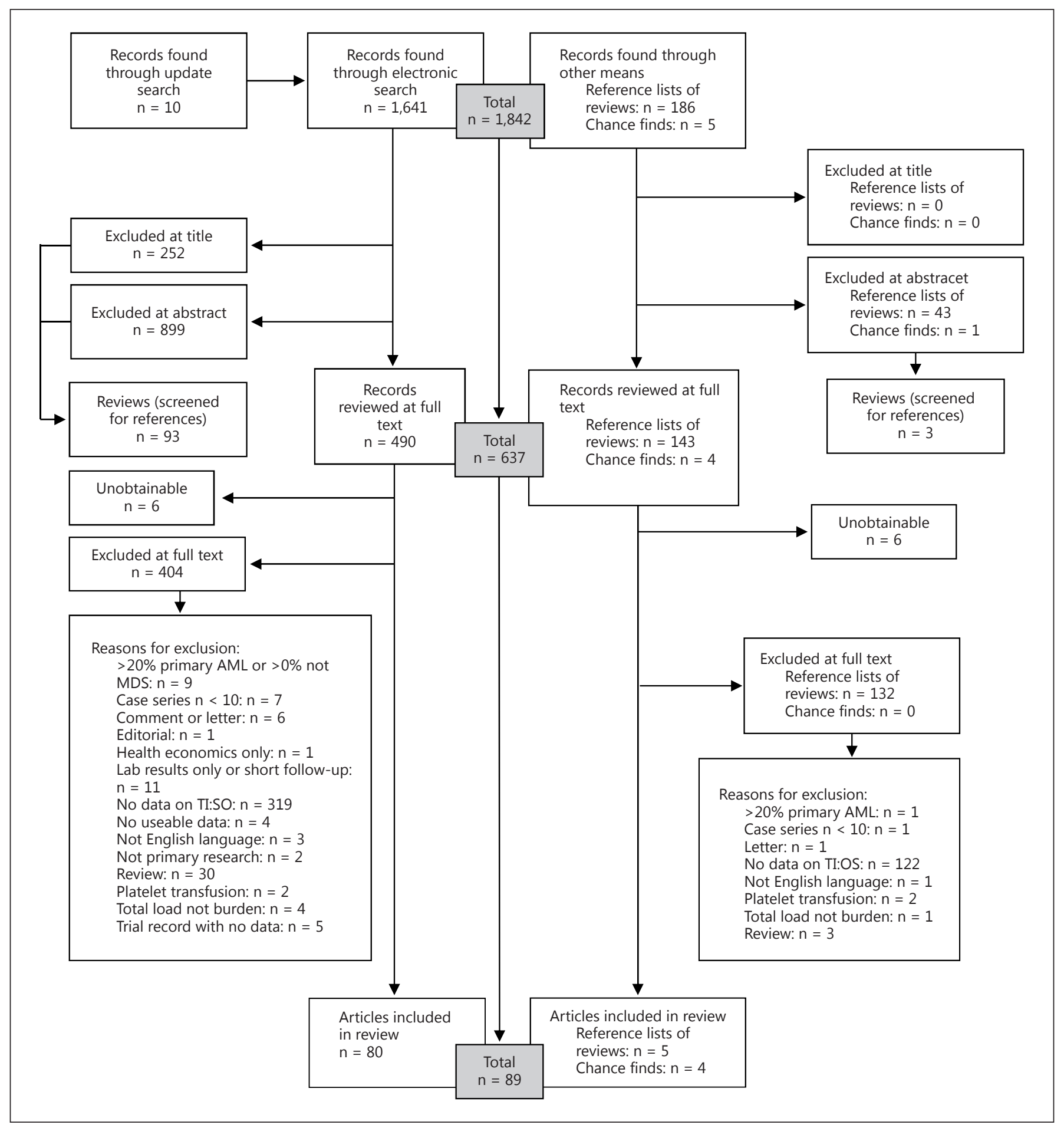

Fig. 1. PRISMA study selection flow chart. 


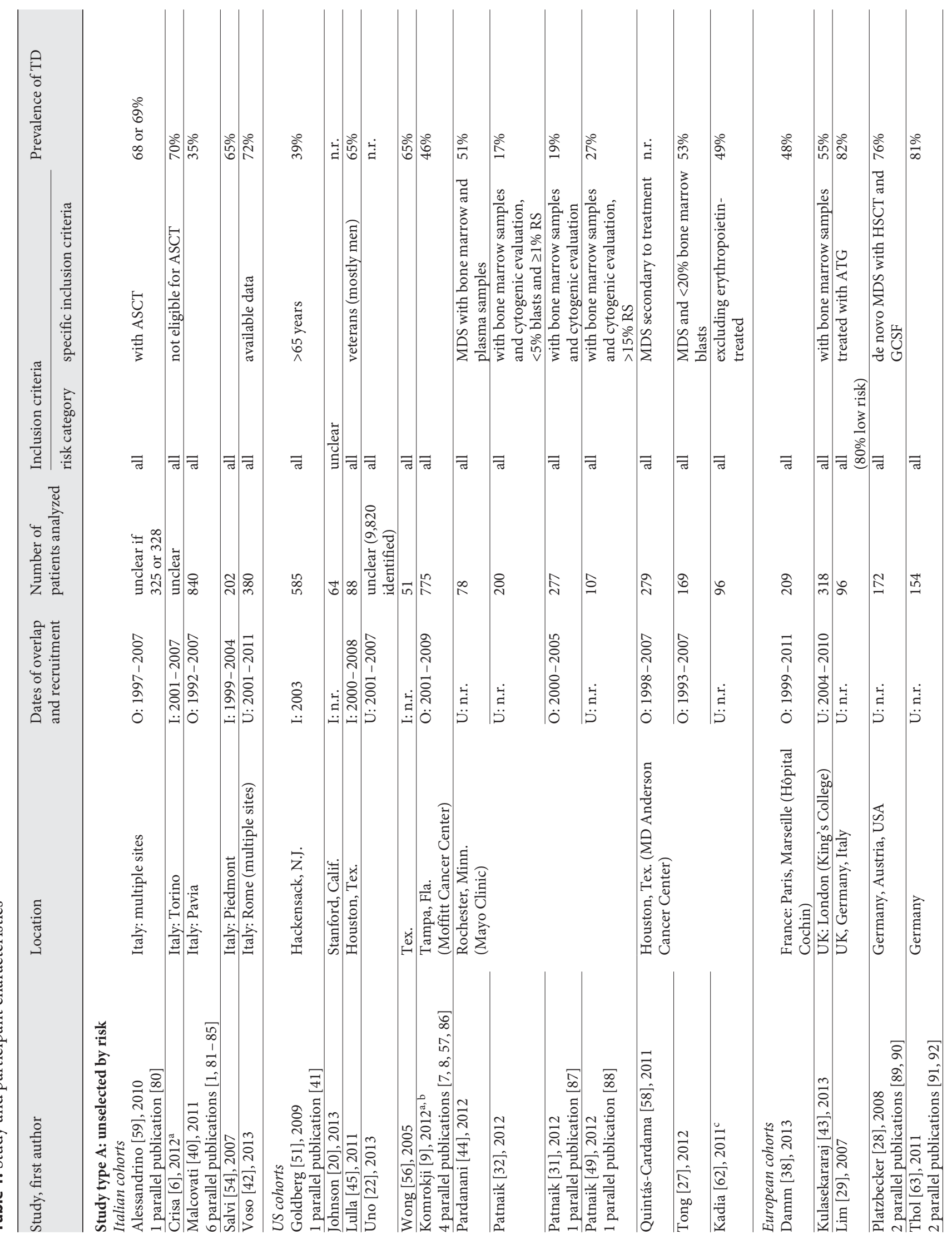




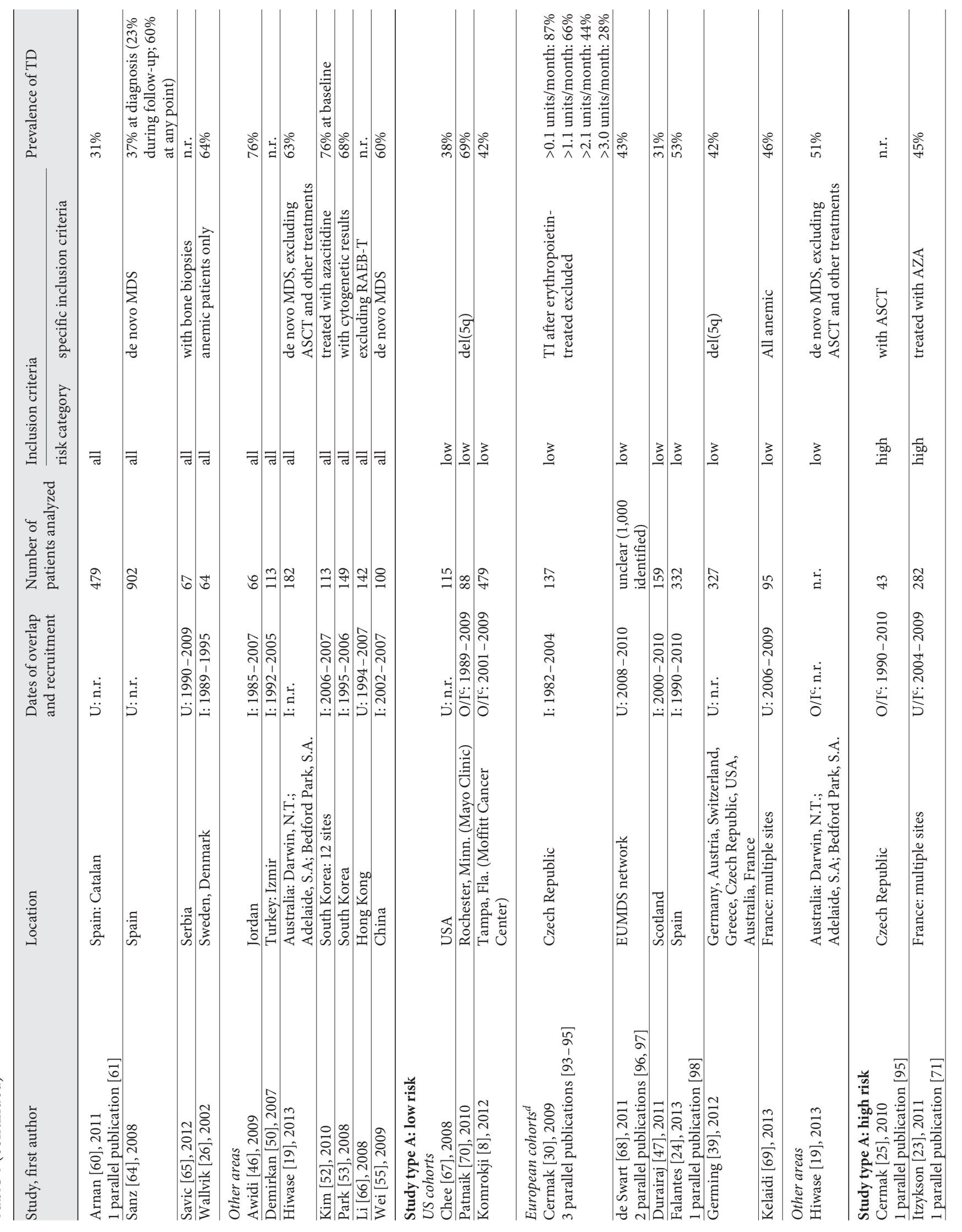




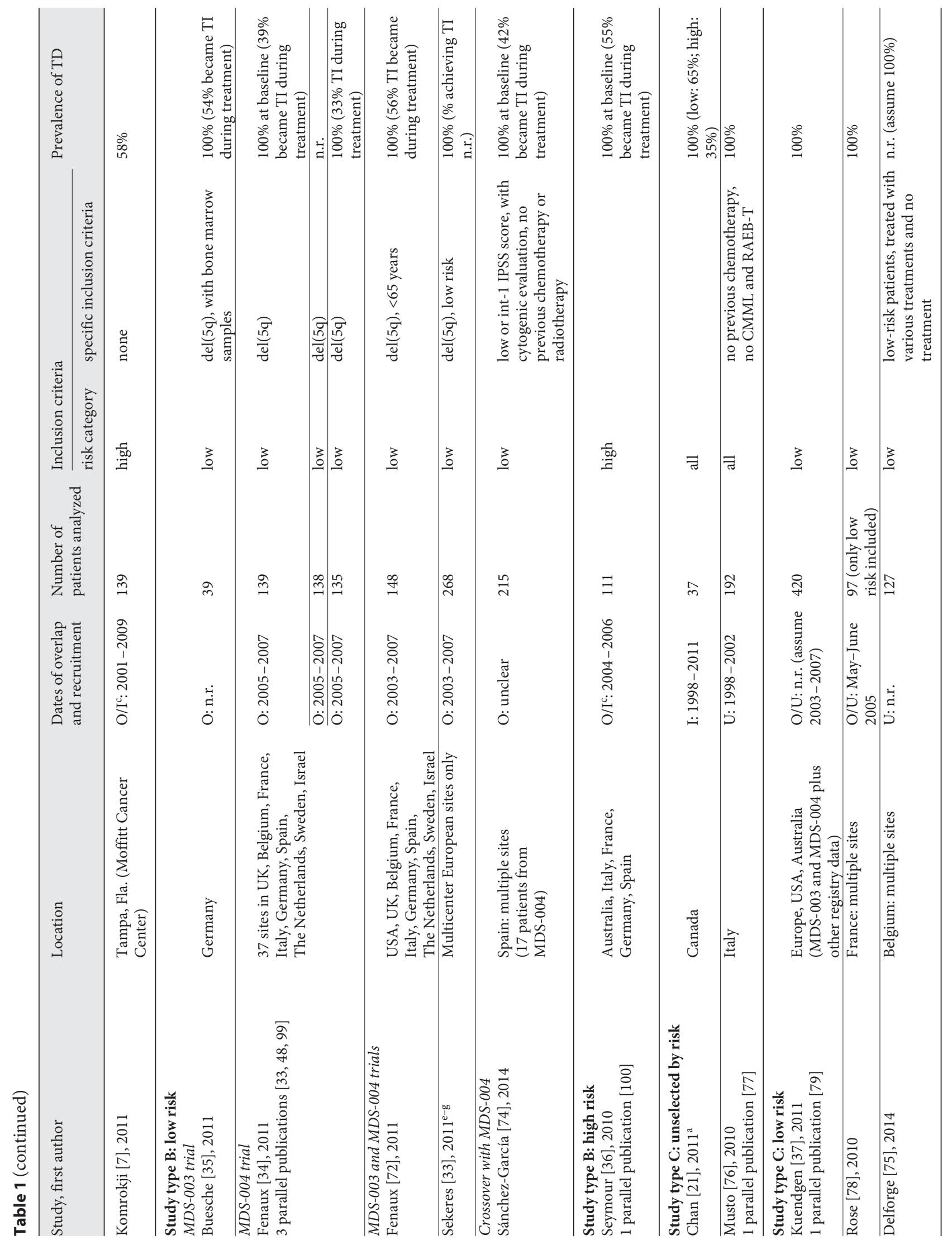




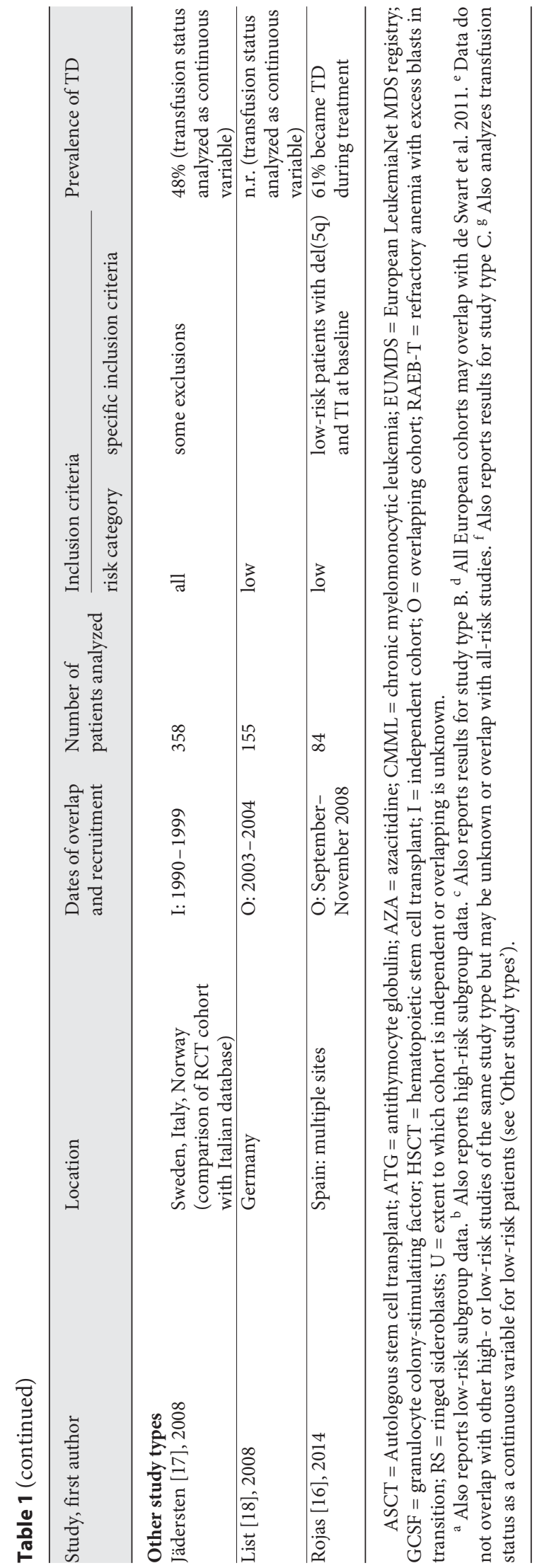

locations over overlapping time periods, and cohorts or parts of cohorts were often included in several studies (table 1).

Results from each study are presented in tables $2-5$. To minimize the impact of double-counting participants on the narrative synthesis, studies that drew data from patient cohorts that were entirely independent from each other are listed first. Studies that drew data from overlapping (or potentially overlapping) patient cohorts are grouped together, and studies for which this could not be ascertained are also grouped together.

As seen in tables 2-5, TI was consistently associated with an OS benefit for patients with MDS, and the effect was usually statistically significant, with only a few exceptions.

For study type A (table 2), 34 studies reported HR or significance of HR in multiple Cox regression analyses. Usually expressed as TD versus TI (values $>1$ indicated better survival for TI patients), HRs ranged from 1.04 [95\% CI not reported (n.r.); $\mathrm{p}=0.85$ ] to 10.95 (95\% CI 3.19-37.53; $\mathrm{p}<0.001$ ) [6]. Studies that recruited only patients with high-risk disease had a lower range of HRs in the multiple Cox regression analyses (1.04; 95\% CI n.r.; $\mathrm{p}=0.85$ and $1.9 ; 95 \%$ CI $1.4-2.6 ; \mathrm{p} \leq 0.0001)[7,23]$ than studies that recruited only patients with low-risk disease [HR range 1.548 (95\% CI 1.092-2.195; $\mathrm{p}=0.014)$ to 10.95 (95\% CI 3.19-37.53; $\mathrm{p}<0.001)][6,24]$. In 2 of the 3 highrisk studies, the HR was nonsignificant $[7,25]$. Of the 34 studies, only 7 did not report a statistically significant $\mathrm{HR}$ [7, 26-31].

Other analyses reported in the type A studies included mean and median survival times, mortality rates at a point in time and univariate Cox regression analyses. In all cases, a numerically favorable survival was reported for TI. Of 37 studies in which statistical significance was reported, only 5 reported a nonsignificant difference [26, 28-30, 32].

All but 2 type B studies drew patient data from one or both of the lenalidomide trials, MDS-003 and MDS-004, and recruited del(5q) patients with low-risk disease. The HRs from the multiple Cox regression analyses, expressed as TI versus TD (values $<1$ indicated better survival for TI patients) ranged from 0.3584 (95\% CI n.r.; p < 0.001) [33] to 0.53 (95\% CI $0.31-0.91 ; \mathrm{p}=0.021$ ) [34] and were statistically significant, apart from 1 that drew a small sample of patients with bone marrow samples available $(\mathrm{n}=$ 39) from the MDS-003 trial [35]. Other analyses of the MDS-003/004 trials reflected a survival advantage for patients achieving TI. Of the two studies that were not an analysis of MDS-003/004, one recruited patients with 


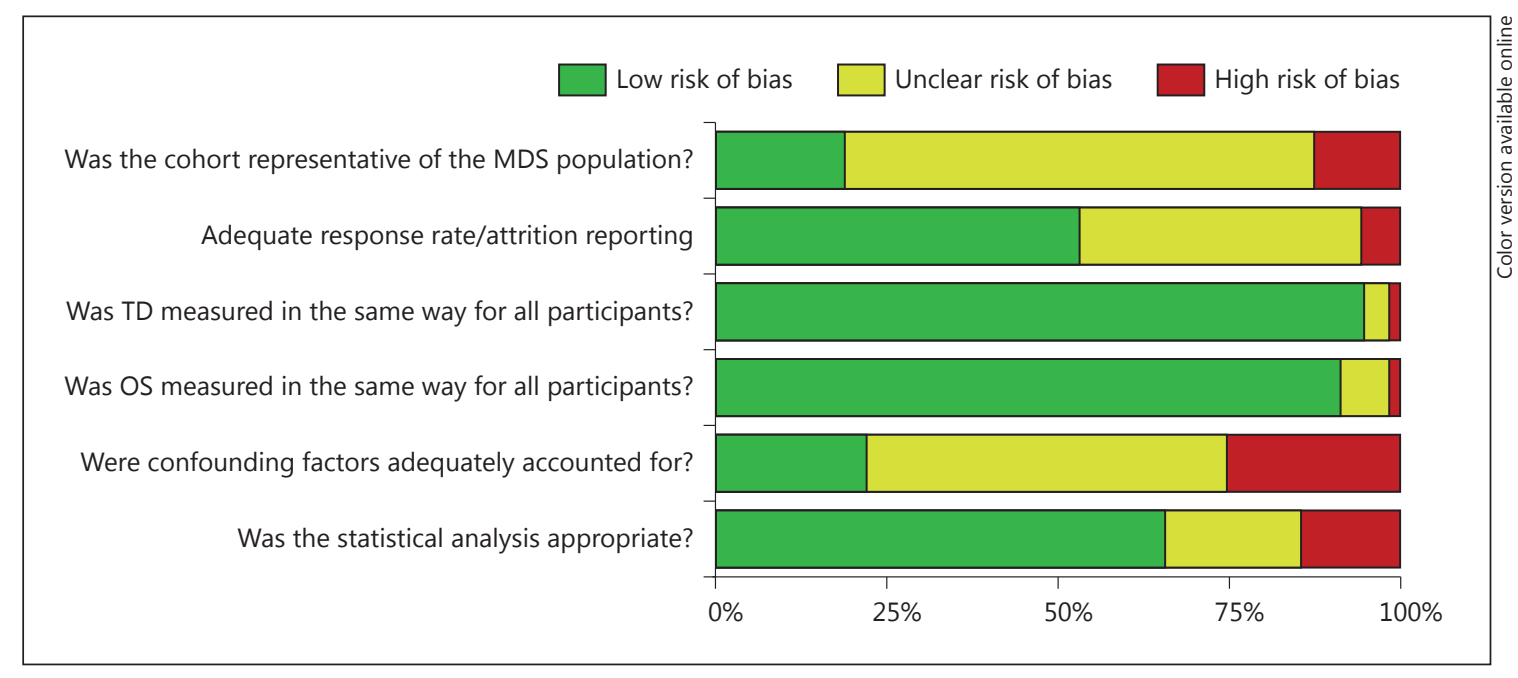

Fig. 2. Risk of bias assessment across the included literature.

high-risk disease and treated them with azacitidine [36] and the other was a reanalysis of two decitabine trials [62]. Both studies reported that achieving TI was associated with a lower risk of death (table 3).

All the type $\mathrm{C}$ studies, whether on low-risk or all-risk patients, reported that low-burden TD was associated with better OS compared with high-burden TD (table 4). HRs were sometimes unexpectedly high $(78.1 ; 95 \%$ CI n.r.; $\mathrm{p}<0.05)$ [21], although this particular analysis had only 14 patients. Large differences in the HRs reported for patients with low-risk disease (range 1.056-78.1) prevented drawing any meaningful observations about whether the association between low-burden TD and OS was different in the low- or all-risk studies. The reanalysis of MDS-003/004 data [37] showed only a small HR between low-burden and high-burden TD patients.

\section{Meta-Analysis}

Analysis 1: Meta-Analysis of All Eligible Studies

(Study Type A)

Ten studies $[6,9,19,24,38-43]$ were included in the meta-analysis of type A studies (regardless of risk category) reporting the multiple Cox regression analysis HR for the OS of TI patients compared with TD patients. Analyzed cohort size ranged from 63 [6] to 840 [40]. Only low- and all-risk subgroups were included in the analysis because none of the 3 studies that recruited patients with high-risk disease were eligible for inclusion due to: (1) an overlap of the patient cohort with other studies [23], (2) the multiple Cox regression analysis in Komrokji et al. [7] had already corrected for transfusion status and (3) data were not reported for the univariate or multiple Cox regression analyses (table 4) [25]. Two of 10 studies [24, 39] selected only patients with low-risk disease whereas the rest selected patients with any severity or risk disease. The meta-analysis showed that TI was associated with a 59\% decrease in the risk of death compared with TD [HR 0.41; 95\% credible interval (CrI) $0.29-0.56$; fig. 3]. The estimated between-study SD was 0.39 (95\% CrI 0.18-0.83), implying moderate heterogeneity between studies in the effects of TI.

A sensitivity analysis was conducted to check the robustness of the estimates by including studies that had reported univariate Cox regression analyses but not a multiple Cox regression analysis [44] and those that had only published Kaplan-Meier curves [26, 45-47]. In it, TI was associated with a $59 \%$ decrease in the risk of death compared with TD (HR 0.41; 95\% CrI 0.32-0.51; fig. 4). The estimated between-study SD was 0.32 (95\% CrI 0.16$0.59)$.

Analysis 2: Meta-Regression for Different Patient Risk Categories (Study Type A)

A random-effects, meta-regression analysis was conducted to assess whether the effect of TI on OS depended on the risk group of the patients included. The same 10 studies used in analysis 1 were included.

The estimated coefficient of the interaction term was an HR of 1.38 (95\% CrI 0.62-3.41), which indicated the possibility of no interaction. Hence, the meta-regression 
Table 2. Study type A results

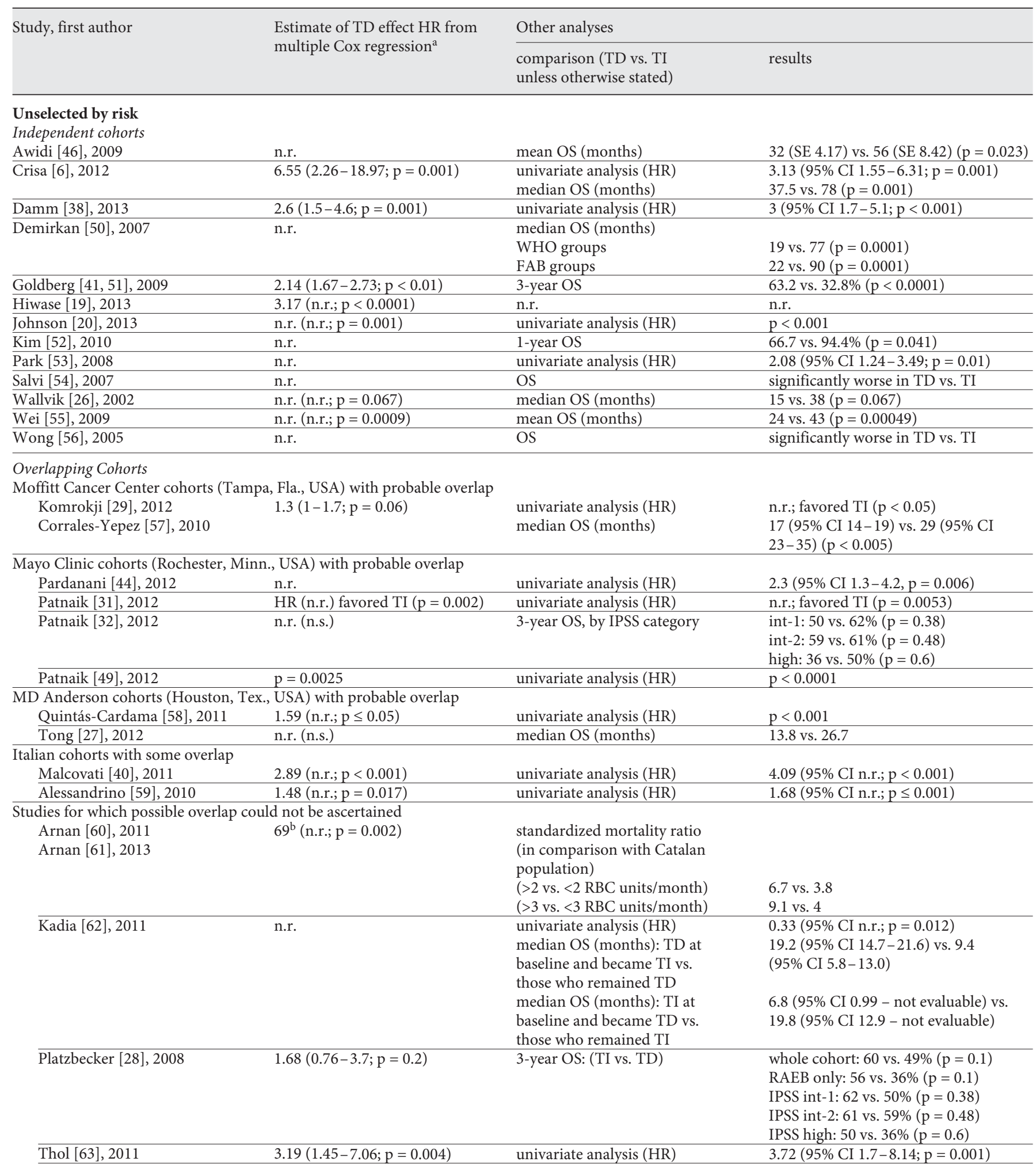

IPSS high: 50 vs. $36 \%(\mathrm{p}=0.6)$ 
Table 2 (continued)

\begin{tabular}{|c|c|c|c|}
\hline \multirow[t]{2}{*}{ Study, first author } & \multirow{2}{*}{$\begin{array}{l}\text { Estimate of TD effect HR from } \\
\text { multiple Cox regression }{ }^{\mathrm{a}}\end{array}$} & \multicolumn{2}{|l|}{ Other analyses } \\
\hline & & $\begin{array}{l}\text { comparison (TD vs. TI } \\
\text { unless otherwise stated) }\end{array}$ & results \\
\hline \multirow[t]{4}{*}{ Sanz [64], 2008} & 8.8 (n.r.; $\mathrm{p}<0.0001$ ) & median OS (months) & \\
\hline & & TD at diagnosis & 19 \\
\hline & & TD development & 60 \\
\hline & & TI & $96(\mathrm{p}<0.0001)$ \\
\hline Uno [22], 2013 & n.r. (significant) & n.r. & n.r. \\
\hline Kulasekararaj [43], 2013 & $2.166(1.3-3.4 ; \mathrm{p}=0.001)$ & n.r. & n.r. \\
\hline Savic [65], 2012 & n.r. (n.r.; $p=0.007$ ) & median OS (months) & $\begin{array}{l}21 \text { vs. end point not reached } \\
(\mathrm{p}=0.00003)\end{array}$ \\
\hline Lulla [45], 2011 & n.r. (n.r.; $p=0.003)$ & univariate analysis (HR) & HR (95\% CI n.r.; p < 0.0001) \\
\hline $\mathrm{Li}[66], 2008$ & n.r. & univariate analysis (HR) & $\operatorname{HR}(95 \%$ CI n.r.; p < 0.001) \\
\hline Lim [29], 2007 & n.r. (n.s.) & univariate analysis (HR) & $7.03(95 \%$ CI $0.95-51.75 ; \mathrm{p}=0.06)$ \\
\hline Voso [42], 2013 & $0.213(0.12-0.379 ; \mathrm{p}<0.001)^{\mathrm{c}}$ & n.r. & n.r. \\
\hline
\end{tabular}

\title{
Low risk
}

Independent cohorts

Cermak [30], 2009

$\geq 0.1$ units/month: $\mathrm{p}=0.0017 \quad$ univariate analysis (HR) of $\geq 1.1$ units/month: $\mathrm{p}=0.0004 \quad$ TD vs. TI at different cut-offs $\geq 2.1$ units/month: $\mathrm{p}=0.0001$ $\geq 3$ units/month: $\mathrm{p}=0.001$

Durairaj [47], 2011 n.r.

Falantes [24], 2013

$1.548(1.092-2.195 ; \mathrm{p}=0.014)$ to define $\mathrm{TD} / \mathrm{TI}$

logistic regression coefficient median OS (months) univariate analysis (HR) n.r. median OS (months) 4-year OS (months)

Hiwase [19], 2013 median OS (months)

$\geq 0.1$ units/month: n.r. $(\mathrm{p}=0.018)$

$\geq 1.1$ units/month: n.r. $(\mathrm{p}=0.001)$

$\geq 2.1$ units/month: n.r. $(\mathrm{p}=0.001)$ $\geq 3$ units/month: n.r. $(\mathrm{p}=0.032)$

2.36 (SE $0.8 ; \mathrm{p}=0.0035)$

19 vs. $32(\mathrm{p}=0.0056)$

$\mathrm{p}=0.001$

22 vs. 60

27.6 vs. $59.9 \%$

52.7 vs. $122.5(\mathrm{p}=0.001)$

Cohorts for which possible overlap could not be ascertained

Chee [67], 2008

n.r.

$10.95(3.19-37.53 ; \mathrm{p}<0.001)$

univariate analysis (HR)

univariate analysis (HR)

HR (95\% CI n.r.; $\mathrm{p}=0.001)$

Crisa [6], 2012

$4.11(2.61-6.46 ; \mathrm{p}=0.0001)$ $3.37(95 \%$ CI $1.52-7.47 ; \mathrm{p}=0.001)$

vivariate analysis (HR)

patients who progressed within

$4.12(95 \%$ CI $2.65-6.4 ; \mathrm{p}=$ n.r. $)$

24 months (defined as increase

in bone marrow blasts to higher

WHO category)

patients who did not progress

$1.51(95 \%$ CI $0.64-3.56 ; \mathrm{p}=$ n.r. $)$

within 24 months

Germing [39], 2012

whole cohort: n.r. $(1.52-3.61$;

whole cohort:

median OS (months) $\quad 44$ vs. $97(\mathrm{p}<0.001)$

$\mathrm{p}=0.0001$

subgroup with RAEB excluded:

correlation coefficient and exp

(coefficient)

correlation coefficient and exp

(coefficient) (RAEB patients

excluded)

\begin{tabular}{lll}
\hline Kelaidi [69], 2013 & n.r. & narrative data only
\end{tabular}

univariate analysis (HR)

univariate analysis (HR)

\author{
$0.8523(2.344)$
}

$0.8155(2.260)$

'baseline transfusion dependence... accurately predicted OS from treatment onset'

Komrokji [8], 2012

n.r.

n.r. $(\mathrm{p}=0.04)$

'significant' ( $p=$ n.r.)

n.r. $(\mathrm{p}=0.04)$

\section{High risk}

Independent cohorts

Cermak [30], 2010

n.r. (n.s.)

Itzykson [23, 71], 2011

$1.9(1.4-2.6 ; \mathrm{p} \leq 0.0001)$

narrative data only median OS (months)

univariate analysis (HR)

'TD did not affect survival' 10.3 vs. $19.2(p=0.0001)$ significant $(\mathrm{p}=$ n.r. $)$

$\mathrm{AZA}=$ Azacitidine; FAB = French American British; n.s. = not significant; RAEB = refractory anemia with excess blasts; RBC $=$ red blood cell.

a $95 \%$ CI; p value; TD vs. TI unless otherwise stated. ${ }^{\mathrm{b}}$ As was reported in the source document. ${ }^{\mathrm{b}}$ TI versus TD.

Transfusion Independence and OS in Patients with MDS
Acta Haematol 2016;136:23-42

DOI: $10.1159 / 000445163$ 
Table 3. Study type B results

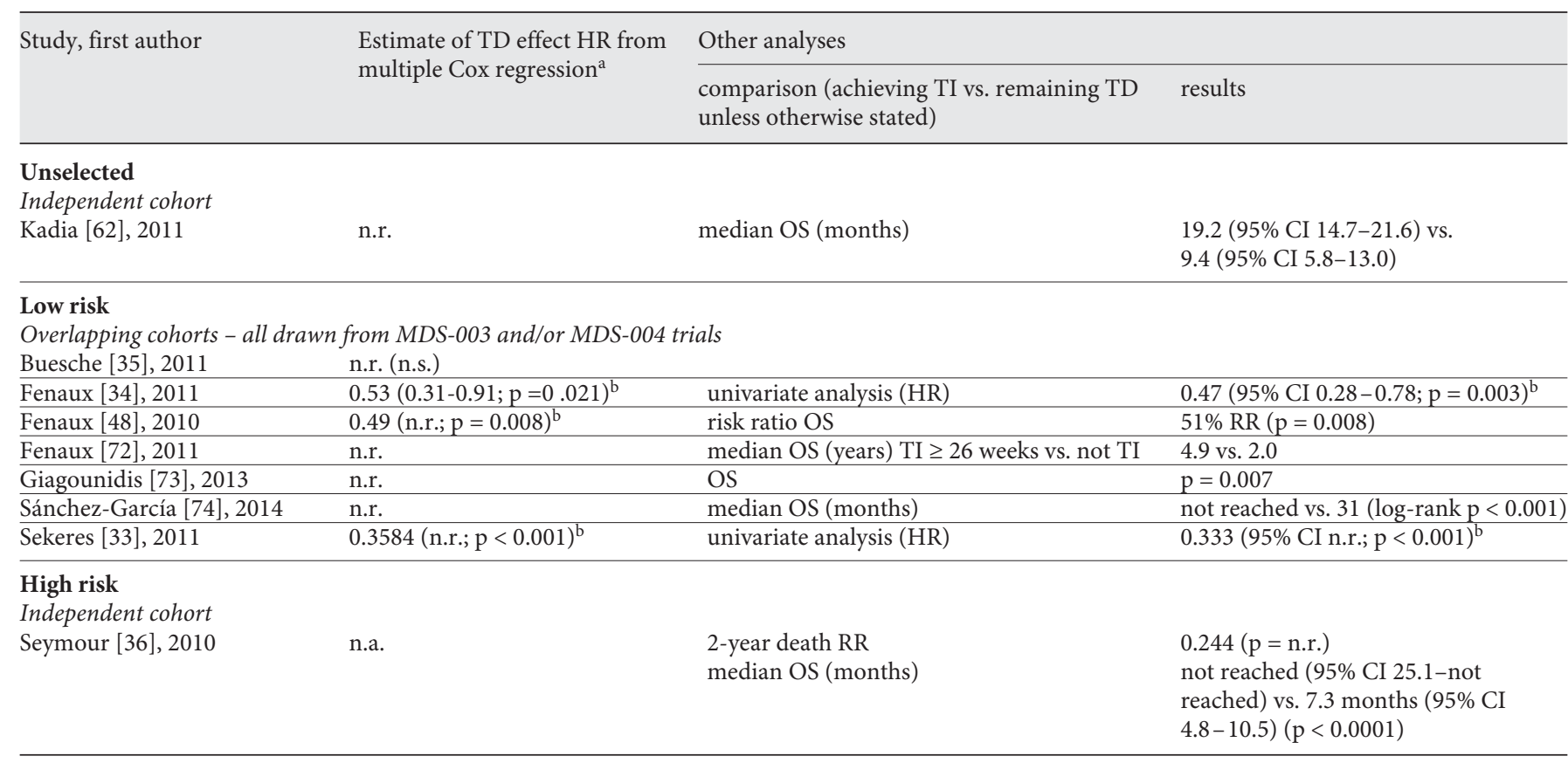

n.a. $=$ Not applicable; $\mathrm{RR}=$ risk ratio/relative risk.

a 95\% CI; p value; achieving TI vs. remaining TD unless otherwise stated. ${ }^{\mathrm{b}}$ TI:TD.

Table 4. Study type C results

\begin{tabular}{|c|c|c|c|}
\hline \multirow[t]{2}{*}{ Study, first author } & \multirow{2}{*}{$\begin{array}{l}\text { Estimate of high-burden versus low- } \\
\text { burden TD from multiple Cox regression }{ }^{\mathrm{a}}\end{array}$} & \multicolumn{2}{|l|}{ Other analyses } \\
\hline & & $\begin{array}{l}\text { comparison (high burden vs. low } \\
\text { burden unless otherwise stated) }\end{array}$ & results \\
\hline \multicolumn{4}{|l|}{ Unselected } \\
\hline \multicolumn{4}{|l|}{ Independent cohorts } \\
\hline Chan [21], 2011 & 18.6 (n.r.; $\mathrm{p}=0.0001)$ & 100-week OS rate & 27 vs. $73.2 \%(p=$ n.r. $)$ \\
\hline \multicolumn{4}{|l|}{ Unclear if overlapping } \\
\hline Delforge [75], 2014 & n.r. & univariate analysis (HR) & $\begin{array}{l}\text { transfusion burden significantly } \\
\text { associated with survival }(p=0.023)\end{array}$ \\
\hline Musto [76, 77], 2010 & $2.62(1.21-5.69 ; \mathrm{p}=0.015)$ & $\begin{array}{l}\text { univariate analysis (HR) } \\
\text { ( }<2 \text { vs. }>2 \text { RBC units/month) }\end{array}$ & $\begin{array}{l}3.87(95 \% \text { CI } 2.21-6.76 \\
\mathrm{p}<0.0001)\end{array}$ \\
\hline \multicolumn{4}{|l|}{ Low risk } \\
\hline \multicolumn{4}{|l|}{ Independent cohorts } \\
\hline Fenaux [48], 2010 & & univariate analysis (HR) & $0.54(95 \% \text { CI n.r.; } \mathrm{p}=0.185)^{\mathrm{b}}$ \\
\hline Rose [78], 2010 & $2.516(1.37-4.61 ; \mathrm{p}=0.0028)$ & & \\
\hline \multicolumn{4}{|c|}{ Overlapping cohorts - some patients from MDS-003 and MDS-004 trials } \\
\hline Kuendgen $[37,79], 2011$ & 1.056 (n.r.; $\mathrm{p}=0.037)$ & & \\
\hline
\end{tabular}


Table 5. Other study types

\begin{tabular}{|c|c|c|c|}
\hline Study, first author & $\begin{array}{l}\text { Estimate of TD effect } \\
\text { HR from multiple } \\
\text { cox regression } \mathrm{HR}^{\mathrm{a}}\end{array}$ & \multicolumn{2}{|l|}{ Other analyses } \\
\hline List [18], 2008 & n.r. & $\begin{array}{l}\text { TS analyzed as continuous variable (RBC units/ } \\
\text { month) multiple Cox regression analysis }\end{array}$ & $1.1(95 \%$ CI $1.01-1.18 ; \mathrm{p}=0.02)$ per unit \\
\hline Rojas [16], 2014 ${ }^{\mathrm{b}}$ & n.r. & Median survival time (months) for TD vs. TI & 66 vs. not reached $(\mathrm{p}=0.527)$ \\
\hline
\end{tabular}

$\mathrm{RBC}=$ Red blood cell; $\mathrm{TS}=$ transfusion status.

a $95 \%$ CI; p value. ${ }^{b}$ Recruited all TI patients at baseline and compared OS in those who became TD with those who did not.

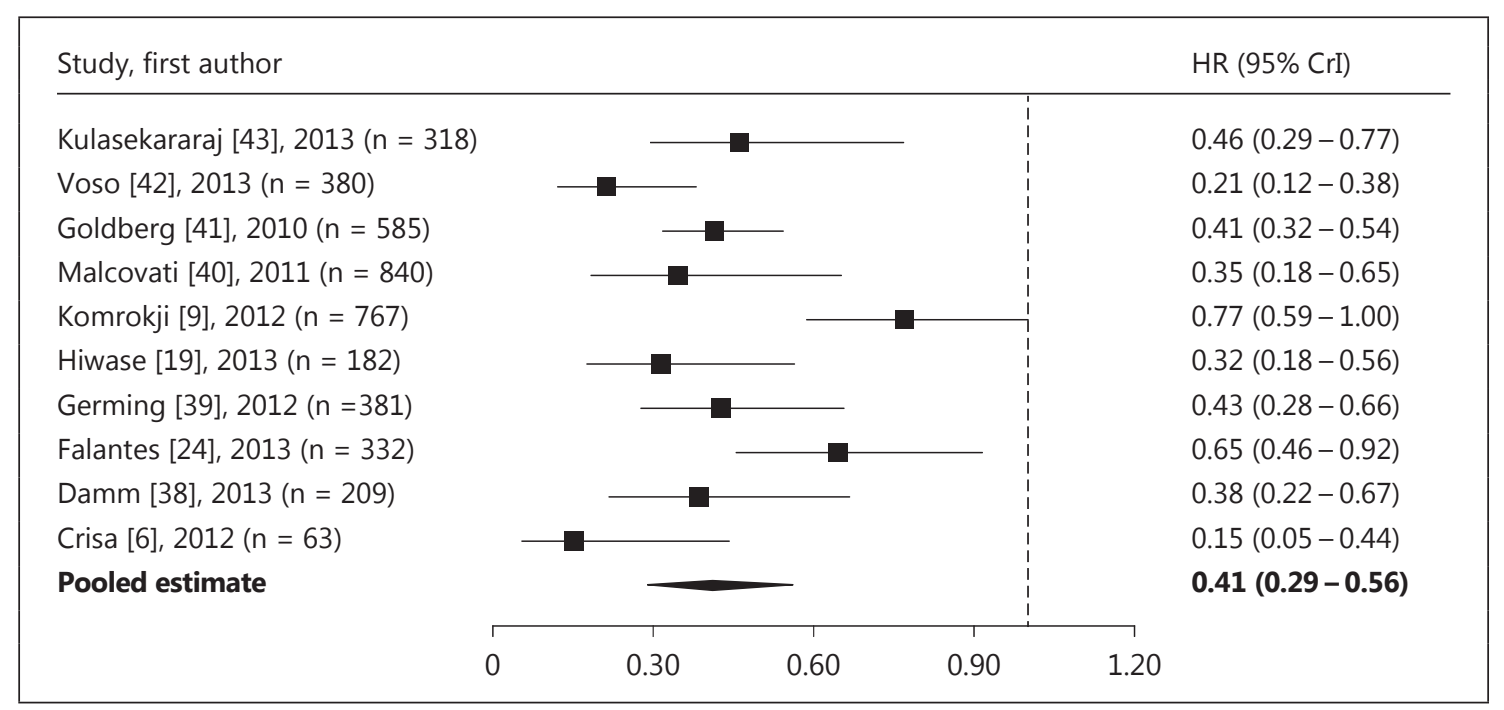

Fig. 3. Forest plot for analysis 1 with all studies that used multiple Cox regression. $\mathrm{n}=$ Number of patients in the cohort. $\mathrm{CrI}=$ Credible interval.

suggested that the magnitude of the benefit on OS from TI was higher for all risk groups, but this was inconclusive.

The analysis also showed that TI was associated with a $62 \%$ decrease in the risk of death compared with TD for the all-risk groups (HR 0.38; 95\% CrI 0.25-0.55) and with a $47 \%$ decrease in the risk of death compared with TD for the low-risk groups (HR 0.53; 95\% CrI 0.25-1.12). The estimated between-study SD was 0.41 (95\% CrI 0.19
0.92), which implied moderate heterogeneity between studies in the effects of TI.

The sensitivity analysis, including studies that did not use multiple Cox regression, showed that TI may have had more benefit on OS among the all-risk groups, but, again, the effect was inconclusive (HR of low-risk group vs. all-risk group $1.45 ; 95 \%$ CrI $0.87-2.50)$. It also showed that TI was associated with a $62 \%$ decrease in the risk of death compared with TD in the all-risk groups (HR 0.38; 


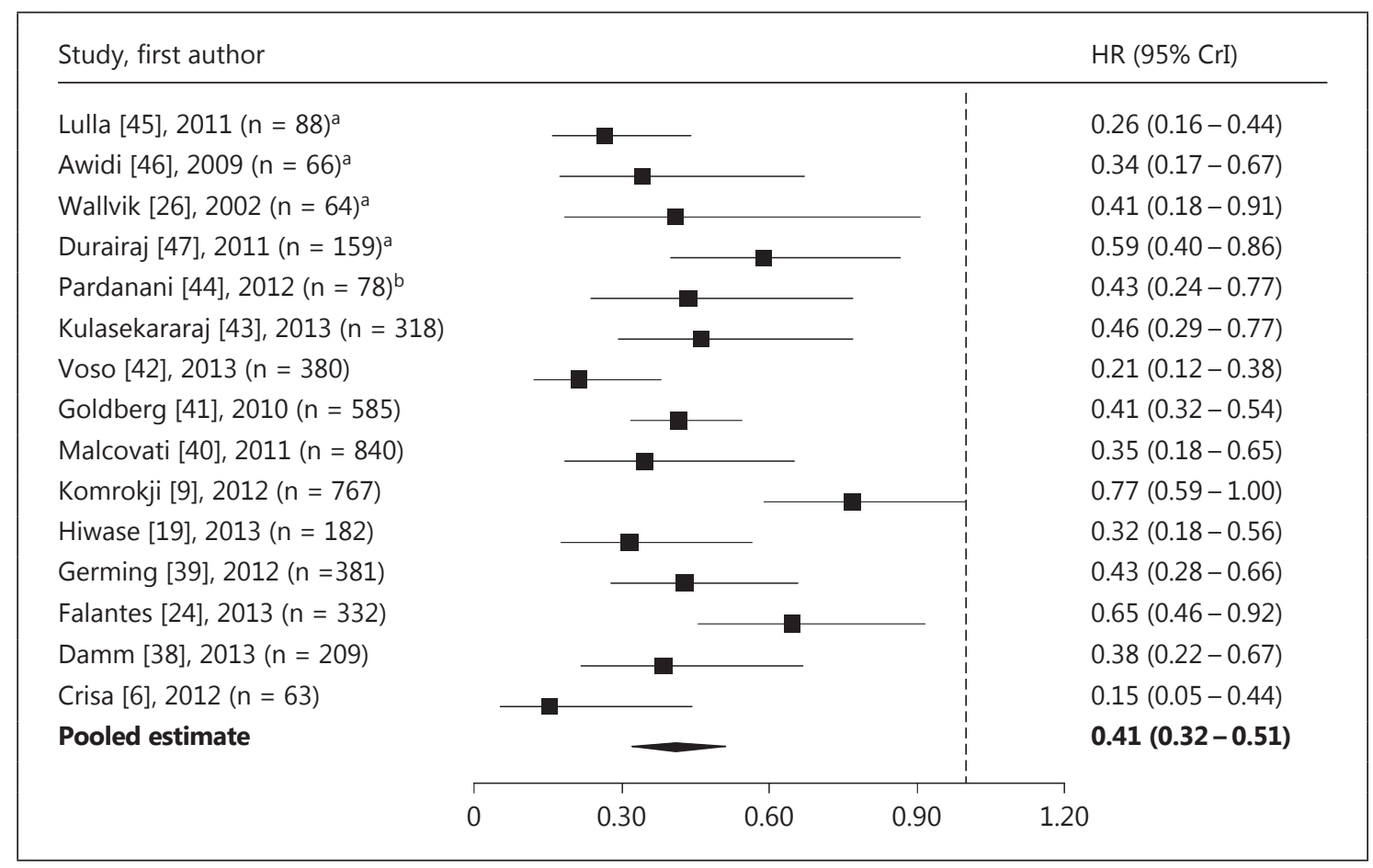

Fig. 4. Forest plot for analysis 1 with studies that used multiple Cox regression, univariate Cox regression and published Kaplan-Meier curves. $\mathrm{n}=$ Number of patients in the cohort. ${ }^{\mathrm{a}}$ The study published Kaplan-Meier curves only. ${ }^{b}$ The study used univariate Cox regression.

95\% CrI 0.29-0.48) and with a $45 \%$ decrease in the risk of death compared with TD in the low-risk groups (HR 0.55; 95\% CrI 0.35-0.87). The estimated between-study SD was 0.31 (95\% CrI 0.16-0.59).

Analysis 3: Patients Who Achieved TI during the Course of the Study (Study Type B)

A meta-analysis was also planned to assess the impact on OS of becoming TI for patients who were TD at baseline, potentially including 3 studies $[33,34,48]$. However, there was too much overlap in the study cohorts to permit a meta-analysis.

\section{Discussion}

This systematic review is the first to investigate the benefits of being TI (study type A) or becoming TI (study type B) on the OS of patients with MDS. The narrative synthesis of findings revealed a consistent reduction in mortality among TI patients compared with TD patients, in both those who were TI at recruitment and those who achieved TI through treatment. In this meta-analysis, the reduction in mortality was estimated to be $59 \%$ for those who were TI at recruitment compared to those who were $\mathrm{TD}$ at recruitment, when all risk categories were included (analysis 1). No meta-analysis was possible for studies in which patients achieved TI through treatment (analysis 3 ), but the $59 \%$ estimate for those who were TI at recruitment falls within the range of reductions for those who achieved TI through treatment, i.e. $47-64 \%$ (HR range $0.53-0.36$ ).

The meta-regression of different risk categories was limited by the small number of studies reporting HRs in the high-risk $(n=0)$, low-risk $(n=2)$ and all-risk $(n=9)$ categories for study type A. The test for an interaction between a risk group and the effect of TI on OS suggested the possibility of no interaction by risk group because the CrI for the interaction was inconclusive. Narrative results for the high-risk studies suggested a much lower range of HRs compared with the all-risk and low-risk studies, but the range of CI of the low-risk and high-risk groups overlapped (table 2). Hence, it is currently impossible to determine whether there is a differential effect of TI on OS, 
depending on the risk category of the patients. Compounding this, 1 limitation for both analyses 1 and 2 is that the all-risk group studies were treated the same, regardless of the proportions of risk categories within each study because not all studies reported these data.

Studies that recruited all TD patients at baseline and compared those with a higher transfusion burden and those with a lower burden (type $\mathrm{C}$ studies) had a very wide range of HRs, preventing any meaningful conclusions from being drawn. Among these were 2 reanalyses of MDS-003/004 data, which reported the smallest HRs in this analysis set. This may be a product of lenalidomide treatment, which may have altered the relative risk of death between the high- and low-burden patients compared with untreated patients.

A small number of studies $(\mathrm{n}=8)[7,25-29,31,35]$ reported that the survival difference between TD and TI patients did not reach statistical significance in the multiple Cox regression analyses. These studies had some unusual characteristics. Komrokji et al. [7] and Cermak et al. [25] were both conducted on patients with high-risk disease, for whom the expected OS may have been too short to show any significant benefit. Platzbecker et al. [28] and Cermak et al. [25] selected patients who had undergone allogeneic stem cell transplant, and the former suggested that this intervention may be protective against the prognostic disadvantage of transfusion requirement. Buesche et al. [35] selected a small subsample of del(5q) patients with available bone marrow samples from the MDS-003 trial, which may have resulted in underpowering or a spectrum bias, both of which could have contributed to the nonsignificant result. Wallvik et al. [26] treated anemic patients (TD and TI) with epoetin and corrected for epoetin response. However, a greater proportion of TI patients responded (54\%) than TD patients $(21 \%)$; therefore, correcting for response is, in part, correcting for transfusion status. The study by Rojas et al. [16] was unique because it recruited all TI patients at baseline and followed them through disease progression, whether they were treated or untreated. The comparison was median survival, which at the last follow-up had not been reached in the TI group, and so the analysis may not reflect the true survival difference between groups. Finally, the patients in Lim et al. [29] were treated with antithymocyte globulin, an intervention that aims to promote hematologic response. Indeed, it appears that the analysis in this study was for baseline TI, which may have been confounded by the approximate $30 \%$ of TD patients who became TI during treatment. The impact of these treatments and patient characteristics on the relationship be- tween TI and OS, however, remains underresearched and is worth exploring in future trials and cohort studies. One further study reported nonsignificant results in 1 analysis [32] in which only those with $<5 \%$ blasts and $\geq 1 \%$ ring sideroblasts were selected, but a significant HR in the 2 other analyses, in which (1) all patients were selected [31] and (2) only those with $>15 \%$ ring sideroblasts were selected [49].

This systematic review has been conducted to high standards following an a priori protocol published in the PROSPERO database. It included comprehensive search techniques that reached data saturation, validation of the study selection and data extraction, a quality assessment of the included studies, an inclusive narrative synthesis and a bespoke meta-analysis. It represents the first formal meta-analysis of this association by systematic review, and care was taken to avoid double-counting within a very challenging data set.

\section{Study Limitations and Future Research}

The definition of TI varied across the literature and was frequently unreported. This may have affected the meta-analysis results, and the potential impact of TI definition on HRs is worthy of further investigation. Due to a lack of suitable data, no meta-analysis was performed for high-risk cohorts and the meta-analysis for low-risk disease included only 2 studies, meaning that the effect of TI within this group was associated with considerable uncertainty. The exclusion of non-English-language studies may have resulted in relevant data being missed. Additionally, the search strategies and study selection process relied on terms included in the abstract. This potential problem was mitigated through the checking of references from a large number of relevant reviews $(n=45)$ to data saturation, which yielded 6 additional included studies. It is therefore likely that most relevant studies were included.

In conclusion, previous studies have suggested that patients with MDS who are TI have better survival relative to those who are TD, but no meta-analysis had been conducted to date. Our findings revealed a consistent, substantial reduction in mortality among TI patients compared with TD patients, confirming the positive TI-OS association. A meta-regression indicated that the impact of TI was higher in the all-risk cohorts versus the low-risk cohorts, but this effect was inconclusive. A similar association was seen for those who acquired TI through treatment. 


\section{Acknowledgments}

This research was supported by a grant from the Celgene Corporation to S.H., S.R., T.G., E.S.E.-H. and A.S. We are grateful to our colleagues Dr. Jeff Anderson and Ms. Vanessa Wright for the administrative support they provided during this research. We would like to thank Chikelue Oragwu, MD, and Jennifer Leslie, $\mathrm{PhD}$, of MediTech Media, for editorial support sponsored by the Celgene Corporation.

\section{References}

1 Malcovati L, Germing U, Kuendgen A, Della Porta MG, Pascutto C, Invernizzi R, Giagounidis A, Hildebrandt B, Bernasconi $\mathrm{P}$, Knipp S, Strupp C, Lazzarino M, Aul C, Cazzola M: Time-dependent prognostic scoring system for predicting survival and leukemic evolution in myelodysplastic syndromes. J Clin Oncol 2007;25:3503-3510.

2 Greenberg PL, Tuechler H, Schanz J, Sanz G, Garcia-Manero G, Sole F, Bennett JM, Bowen D, Fenaux P, Dreyfus F, Kantarjian H, Kuendgen A, Levis A, Malcovati L, Cazzola M, Cermak J, Fonatsch C, Le Beau MM, Slovak ML, Krieger O, Luebbert M, Maciejewski J, Magalhaes SM, Miyazaki Y, Pfeilstocker M, Sekeres M, Sperr WR, Stauder R, Tauro S, Valent $\mathrm{P}$, Vallespi $\mathrm{T}$, van de Loosdrecht AA, Germing U, Haase D: Revised international prognostic scoring system for myelodysplastic syndromes. Blood 2012;120:2454-2465.

3 Pardanani A, Tefferi A: Prognostic relevance of anemia and transfusion dependency in myelodysplastic syndromes and primary myelofibrosis. Haematologica 2011;96:8-10.

4 Valent P, Krieger O, Stauder R, Wimazal F, Nosslinger T, Sperr WR, Sill H, Bettelheim P, Pfeilstocker M: Iron overload in myelodysplastic syndromes (MDS) - diagnosis, management, and response criteria: a proposal of the Austrian MDS platform. Eur J Clin Invest 2008;38:143-149.

5 Malcovati L, Cazzola M: The relevance of transfusion-dependency in the prognostic assessment of patients with myeloid neoplasms. Am J Hematol 2011;86:241-243.

6 Crisa E, Foli C, Passera R, Darbesio A, Garvey KB, Boccadoro M, Ferrero D: Long-term follow-up of myelodysplastic syndrome patients with moderate/severe anaemia receiving human recombinant erythropoietin +13 -cisretinoic acid and dihydroxylated vitamin D3: independent positive impact of erythroid response on survival. Br J Haematol 2012;158: 99-107.

7 Komrokji RS, Al Ali NH, Corrales-Yepez M, Padron E, Epling-Burnette PK, Lancet JE, List AF: Impact of iron overload in higher risk myelodysplastic syndromes. Blood Conference of the 53rd Annual Meeting of the American Society of Hematology, San Diego, 10-13 December 2011. Conference Publication 2011; 118:18.
8 Komrokji RS, Corrales-Yepez M, Al Ali NH, Padron E, Zhang L, Epling-Burnette PK, Pinilla-Ibarz J, Lancet JE, List AF: Validation of the lower risk MD Anderson Prognostic Scoring System for Patients with Myelodysplastic Syndromes. Blood Conference of the 54th Annual Meeting of the American Society of Hematology, Atlanta, 8-11 December 2012. Conference Publication 2012;120:16.

9 Komrokji RS, Corrales-Yepez M, KharfanDabaja MA, Al Ali NH, Padron E, Rollison DE, Pinilla-Ibarz J, Zhang L, Epling-Burnette PK, Lancet JE, List AF: Hypoalbuminemia is an independent prognostic factor for overall survival in myelodysplastic syndromes. Am J Hematol 2012;87:1006-1009.

10 Preferred Reporting Items for Systematic Reviews and Meta-Analyses (PRISMA) Statement 2014.

11 Centre for Reviews and Dissemination: Systematic reviews. CRD's guidance for undertaking reviews in healthcare, York, 2009.

12 Hayden JA, van der Windt DA, Cartwright JL, Cote P, Bombardier C: Assessing bias in studies of prognostic factors. Ann Intern Med 2013;158:280-286.

13 Greenberg P, Cox C, LeBeau MM, Fenaux P, Morel P, Sanz G, Sanz M, Vallespi T, Hamblin T, Oscier D, Ohyashiki K, Toyama K, Aul C, Mufti G, Bennett J: International scoring system for evaluating prognosis in myelodysplastic syndromes. Blood 1997;89:20792088.

14 Vardiman JW, Thiele J, Arber DA, Brunning RD, Borowitz MJ, Porwit A, Harris NL, Le Beau MM, Hellstrom-Lindberg E, Tefferi A, Bloomfield CD: The 2008 revision of the World Health Organization (WHO) classification of myeloid neoplasms and acute leukemia: rationale and important changes. Blood 2009;114:937-951.

15 Guyot P, Ades AE, Ouwens MJ, Welton NJ: Enhanced secondary analysis of survival data: reconstructing the data from published $\mathrm{Ka}$ plan-Meier survival curves. BMC Med Res Methodol 2012;12:9.

16 Rojas SM, Diez-Campelo M, Luno E, Cabrero M, Pedro C, Calabuig M, Nomdedeu B, Cedena T, Arrizabalaga B, Garcia M, Cervero C, Collado R, Azaceta G, Ardanaz MT, Munoz JA, Xicoy B, Rodriguez MJ, Bargay J, Morell MJ, Simiele A, Del CC: Transfusion dependence development and disease evolution in patients with MDS and $\operatorname{del}(5 q)$ and without transfusion needs at diagnosis. Leuk Res 2014; 38:304-309.
17 Jädersten M, Malcovati L, Dybedal I, Della Porta MG, Invernizzi R, Montgomery SM, Pascutto C, Porwit A, Cazzola M, HellstromLindberg E: Erythropoietin and granulocytecolony stimulating factor treatment associated with improved survival in myelodysplastic syndrome. J Clin Oncol 2008;26:3607-3613.

18 List AF, Giagounidis A, Brandenburg N, Wride K, Glasmacher A, Germing U: Risk factors for AML transformation and mortality in transfusion-dependent deletion $5 \mathrm{q}$ MDS. Haematologica 2008;93:287.

19 Hiwase DK, Kutyna MM, Chhetri R, Howell S, Harrison PB, Nath SV, Nath LS, Wickham N, Szabo F, Hui C-H, Ross D, Gray J, Melo JV, Bardy P, To LB: Transfusion dependency is associated with inferior survival even in very low and low risk IPSS-R patients. Blood Conference of the 55th Annual Meeting of the American Society of Hematology, New Orleans, 7-10 December 2013. Conference Publication 2013;122:21

20 Johnson RC, Greenberg PL, Gratzinger D: CD271+ mesenchymal stromal cell density is high in poor-risk MDS and independently predicts overall survival. Blood Conference of the 55th Annual Meeting of the American Society of Hematology, New Orleans, 7-10 December 2013. Conference Publication 2013; 122:21.

21 Chan ALS, Shapiro R, Buckstein R, Lin Y, Callum J, Chodirker L, Lee CD, Lam A, Mamedov A, Wells RA: Initial transfusion rate predicts survival in MDS. Blood Conference of the 53rd Annual Meeting of the American Society of Hematology, San Diego, 10-13 December 2011. Conference Publication 2011;118:18.

22 Uno H, Cronin A, Schrag D, Abel GA: Derivation and validation of the SEER-Medicare MDS risk score (SMMRS). Journal of Clinical Oncology Conference of the 2013 Annual Meeting of the American Society of Clinical Oncology, Chicago, 31 May to 4 June 2013. Conference Publication 2013;31:20.

23 Itzykson R, Thepot S, Quesnel B, Dreyfus F, Beyne-Rauzy O, Turlure P, Vey N, Recher C, Dartigeas C, Legros L, Delaunay J, Salanoubat C, Visanica S, Stamatoullas A, Isnard F, Marfaing-Koka A, de Botton S, Chelghoum Y, Taksin AL, Plantier I, Ame S, Boehrer S, Gardin C, Beach CL, Ades L, Fenaux P; Groupe Francophone des Myelodysplasies: Prognostic factors for response and overall survival in 282 patients with higher-risk myelodysplastic syndromes treated with azacitidine. Blood 2011;117:403-411. 
24 Falantes JF, Calderon C, Marquez Malaver FJ, Alonso D, Martin NA, Carrillo E, Martino ML, Montero I, Gonzalez J, Parody R, Espigado I, Perez-Simon JA: Clinical prognostic factors for survival and risk of progression to acute myeloid leukemia in patients with myelodysplastic syndromes with $<10 \%$ marrow blasts and nonunfavorable cytogenetic categories. Clin Lymphoma Myeloma Leuk 2013;13:144-152.

25 Cermak J, Vitek A, Markova M, Cetkovsky P: Combination chemotherapy leading in advanced MDS patients to a rapid clearance of bone marrow blasts prior to stem cell transplantation (SCT) is superior to up-front SCT even with intensified conditioning for a long survival term. Blood Conference of the 52nd Annual Meeting of the American Society of Hematology, Orlando, 4-7 December 2010. Conference Publication 2010;116:19.

26 Wallvik J, Stenke L, Bernell P, Nordahl G, Hippe E, Hast R: Serum erythropoietin (EPO) levels correlate with survival and independently predict response to EPO treatment in patients with myelodysplastic syndromes. Eur J Haematol 2002;68:180-186.

27 Tong WG, Quintas-Cardama A, Kadia T, Borthakur G, Jabbour E, Ravandi F, Faderl S, Wierda W, Pierce S, Shan J, Bueso-Ramos C, Kantarjian H, Garcia-Manero G: Predicting survival of patients with hypocellular myelodysplastic syndrome: development of a disease-specific prognostic score system. Cancer 2012;118:4462-4470.

28 Platzbecker U, Bornhauser M, Germing U, Stumpf J, Scott BL, Kroger N, Schwerdtfeger R, Bohm A, Kobbe G, Theuser C, Rabitsch W, Valent P, Sorror ML, Ehninger G, Deeg HJ: Red blood cell transfusion dependence and outcome after allogeneic peripheral blood stem cell transplantation in patients with de novo myelodysplastic syndrome (MDS). Biol Blood Marrow Transplant 2008;14:1217-1225.

29 Lim ZY, Killick S, Germing U, Cavenagh J, Culligan D, Bacigalupo A, Marsh J, Mufti GJ: Low IPSS score and bone marrow hypocellularity in MDS patients predict hematological responses to antithymocyte globulin. Leukemia 2007;21:1436-1441.

30 Cermak J, Kacirkova P, Mikulenkova D, Michalova K: Impact of transfusion dependency on survival in patients with early myelodysplastic syndrome without excess of blasts. Leuk Res 2009;33:1469-1474.

31 Patnaik MM, Hanson CA, Hodnefield JM, Lasho TL, Finke CM, Knudson RA, Ketterling RP, Pardanani A, Tefferi A: Differential prognostic effect of IDH1 versus IDH2 mutations in myelodysplastic syndromes: a Mayo Clinic study of 277 patients. Leukemia 2012;26:101105.

32 Patnaik MM, Hanson CA, Sulai NH, Hodnefield JM, Knudson RA, Ketterling RP, Lasho TL, Tefferi A: Prognostic irrelevance of ring sideroblast percentage in World Health Organization-defined myelodysplastic syndromes without excess blasts. Blood 2012;119:56745677.
33 Sekeres M, Giagounadis A, List A, Sanz G, Selleslag D, Backstrom J, Fu T, Fenaux P: Predictive factors for overall survival (OS) and AML progression in a large cohort of patients with low-/int-1-risk MDS with del(5q) treated with lenalidomide (LEN). Haematologica 2011;96: 481.

34 Fenaux P, Giagounidis A, Selleslag D, BeyneRauzy O, Mufti G, Mittelman M, Muus P, Te BP, Sanz G, Del CC, Guerci-Bresler A, Nilsson L, Platzbecker U, Lubbert M, Quesnel B, Cazzola M, Ganser A, Bowen D, Schlegelberger B, Aul C, Knight R, Francis J, Fu T, Hellström-Lindberg E; MDS-004 Lenalidomide del5q Study Group: A randomized phase 3 study of lenalidomide versus placebo in RBC transfusion-dependent patients with low-/ intermediate-1-risk myelodysplastic syndromes with del5q. Blood 2011;118:37653776.

35 Buesche G, Giagounidis A, Gohring G, Schlegelberger B, Dieck S, Knight R, Aul C, Kreipe HH: Prognosis of low- or intermediate-1-risk MDS with del(5q) chromosome abnormality during lenalidomide therapy depends on the capacity of the neoplastic stem cell to differentiate into maturing erythroid committed stem cells. Blood Conference of the 53rd Annual Meeting of the American Society of Hematology, San Diego, 10-13 December 2011. Conference Publication 2011; 118:18.

36 Seymour JF, Santini V, Fenaux P, Giagounidis AAN, Sanz GF, Finelli C, Lucy LM, Backstrom J, Beach CL: Achievement of red blood cell (RBC) transfusion independence with azacitidine (AZA) leads to improved survival in patients with higher-risk myelodysplasias regardless of baseline transfusion needs. Blood Conference of the 52nd Annual Meeting of the American Society of Hematology, Orlando, 4-7 December 2010. Conference Publication 2010;116:19.

37 Kuendgen A, Lauseker M, List AF, Fenaux P, Giagounidis A, Brandenburg N, Backstrom J, Glasmacher A, Hasford J, Germing U: Lenalidomide treatment is not related to AML progression risk but is associated with a survival benefit in RBC transfusion-dependent patients with IPSS low-or int-1-risk MDS with del5q: results from a comparative study. Blood Conference of the 53rd Annual Meeting of the American Society of Hematology, San Diego, 10-13 December 2011. Conference Publication 2011;118:18.

38 Damm F, Chesnais V, Nagata Y, Yoshida K, Scourzic L, Okuno Y, Itzykson R, Sanada M, Shiraishi Y, Gelsi-Boyer V, Renneville A, Miyano S, Mori H, Shih LY, Park S, Dreyfus F, Guerci-Bresler A, Solary E, Rose C, Cheze S, Prebet T, Vey N, Legentil M, Duffourd Y, de Botton S, Preudhomme C, Birnbaum D, Bernard OA, Ogawa S, Fontenay M, Kosmider O: BCOR and BCORL1 mutations in myelodysplastic syndromes and related disorders. Blood 2013;122:3169-3177.
39 Germing U, Lauseker M, Hildebrandt B, Symeonidis A, Cermak J, Fenaux P, Kelaidi C, Pfeilstocker M, Nosslinger T, Sekeres M, Maciejewski J, Haase D, Schanz J, Seymour J, Kenealy M, Weide R, Lubbert M, Platzbecker U, Valent P, Gotze K, Stauder R, Blum S, Kreuzer KA, Schlenk R, Ganser A, Hofmann WK, Aul C, Krieger O, Kundgen A, Haas R, Hasford J, Giagounidis A: Survival, prognostic factors and rates of leukemic transformation in 381 untreated patients with MDS and $\operatorname{del}(5 \mathrm{q})$ : a multicenter study. Leukemia 2012;26:12861292.

40 Malcovati L, Della Porta MG, Strupp C, Ambaglio I, Kuendgen A, Nachtkamp K, Travaglino E, Invernizzi R, Pascutto C, Lazzarino M, Germing U, Cazzola M: Impact of the degree of anemia on the outcome of patients with myelodysplastic syndrome and its integration into the WHO classification-based Prognostic Scoring System (WPSS). Haematologica 2011;96:1433-1440.

41 Goldberg SL, Chen E, Corral M, Guo A, Mody-Patel N, Pecora AL, Laouri M: Incidence and clinical complications of myelodysplastic syndromes among United States Medicare beneficiaries (review). J Clin Oncol 2010;28: 2847-2852.

42 Voso M, Fenu S, Latagliata R, Buccisano F, Piciocchi A, Aloe-Spiriti M, Breccia M, Criscuolo M, Andriani A, Mancini S, Niscola P, Naso V, Nobile C, Piccioni A, D'Andrea M, D’Addosio A, Leone G, Venditti A: Revised International Prognostic Scoring System (IPSS) predicts survival and leukemic evolution of myelodysplastic syndromes significantly better than IPSS and WHO Prognostic Scoring System: validation by the Gruppo Romano Mielodisplasie Italian regional database. J Clin Oncol 2013;31:2671-2677.

43 Kulasekararaj AG, Smith AE, Mian SA, Mohamedali AM, Krishnamurthy P, Lea NC, Gaken J, Pennaneach C, Ireland R, Czepulkowski B, Pomplun S, Marsh JC, Mufti GJ: TP53 mutations in myelodysplastic syndrome are strongly correlated with aberrations of chromosome 5 , and correlate with adverse prognosis. Br J Haematol 2013;160:660672.

44 Pardanani A, Finke C, Lasho TL, Al-Kali A, Begna KH, Hanson CA, Tefferi A: IPSS-independent prognostic value of plasma CXCL10, IL-7 and IL-6 levels in myelodysplastic syndromes. Leukemia 2012;26:693-699.

45 Lulla PD, Arce-Lara C, Yellapragada S: Single center experience of prognostic factors and survival outcomes among veterans with MDS: a retrospective analysis. Journal of General Internal Medicine Conference of the 34th Annual Meeting of the Society of General Internal Medicine, Phoenix, 4-7 May 2011.

46 Awidi A, Magableh A, Taimeh Z, Ayyad H, Bsoul N, Tarawneh M: Primary myelodysplastic syndrome in Jordan: a single-centre experience. Med Princ Pract 2009;18:351355 
47 Durairaj S, Chew S, Hyslop A, Keenan N, Groves MJ, Tauro S: Predicted costs of ironchelators in myelodysplastic syndromes: a 10year analysis based on actual prevalence and red cell transfusion rates. Am J Hematol 2011; 86:406-410.

48 Fenaux P, Giagounidis A, Beyne-Rauzy O, Mufti G, Mittelman M, Muus P, Te BP, Sanz G, Cazzola M, Backstrom J, Fu T, HellströmLindberg E: Prognostic factors of long-term outcomes in low- or int-1-risk MDS with del5q treated with lenalidomide (LEN): results from a randomized phase 3 trial (MDS004). Blood Conference of the 52nd Annual Meeting of the American Society of Hematology, Orlando, 4-7 December 2010. Conference Publication 2010;116:19.

49 Patnaik MM, Lasho TL, Hodnefield JM, Knudson RA, Ketterling RP, Garcia-Manero G, Steensma DP, Pardanani A, Hanson CA, Tefferi A: SF3B1 mutations are prevalent in myelodysplastic syndromes with ring sideroblasts but do not hold independent prognostic value. Blood 2012;119:569-572.

50 Demirkan F, Alacacioglu I, Piskin O, Ozsan HG, Akinci B, Ozcan AM, Yavuzsen T, Yuksel E, Undar B: The clinical, haematological and morphological profile of patients with myelodysplastic syndromes: a single institution experience from Turkey. Leuk Lymphoma 2007;48:1372-1378.

51 Goldberg SL, Chen E, Corral M, Guo A, Laouri M: P099 Influence of RBC transfusions on clinical outcomes among USA Medicare beneficiaries with newly diagnosed myelodysplastic syndromes. Leuk Res 2009; 33:S116.

52 Kim DY, Lee JH, Lee JH, Lee KH, Kim YK, Ahn JS, Kim HJ, Kim I, Yoon SS, Park S: Comparison of various criteria in predicting treatment response and prognosis of patients with myelodysplastic syndrome treated with azacitidine. Ann Hematol 2010;89:15-23.

53 Park MJ, Kim HJ, Kim SH, Kim DH, Kim SJ, Jang JH, Kim K, Kim WS, Jung CW: Is the International Prognostic Scoring System (IPSS) still standard in predicting prognosis in patients with myelodysplastic syndrome? External validation of the WHO classification-based Prognostic Scoring System (WPSS) and comparison with IPSS. Eur J Haematol 2008;81:364-373.

54 Salvi F, Gioia D, Cilloni D, Audisio E, Boccomini C, Bonferroni M, Cametti G, Ciravegna G, Darbesio A, Dellacasa C, Ferrero D, Freilone R, Lunghi M, Gallamini A, Gaidano G, Girotto M, Marmont F, Tonso A, Saglio G, Levis A: Prognostic role of transfusion requirement in myelodysplastic syndromes. Leuk Res 2007;31:S96.

55 Wei J, Zhou XF, Zhou JF, Chen Y: Analysis of WHO-based Prognostic Scoring System (WPSS) of myelodysplastic syndrome and its comparison with the International Prognostic Scoring System (IPSS) in 100 Chinese patients. Chin J Cancer Res 2009;21:50-55.
56 Wong L, Dobin S, Ladd D, Koss W, Wajima T: P-3 Transfusion Dependency: Independent Prognostic Factor for Patients with Myelodysplastic Syndrome. BookSC, 2005, pp S25-S26.

57 Corrales-Yepez M, Lancet JE, List AF, Kharfan-Dabaja MA, Field T, Padron E, Komrokji RS: Validation of the newly proposed MD Anderson prognostic risk model for patients with myelodysplastic syndromes. Blood Conference of the 52nd Annual Meeting of the American Society of Hematology, Orlando, 4-7 December 2010. Conference Publication 2010;116:19.

58 Quintas-Cardama A, Kim H, Shan J, Jabbour E, Faderl S, Wierda WG, Ravandi F, Kadia T, Wang SA, Pierce S, Kantarjian HM, GarciaManero G: A prognostic model of therapyrelated myelodysplastic syndrome for predicting survival and transformation to acute myeloid leukemia. Blood Conference of the 53rd Annual Meeting of the American Society of Hematology, San Diego, 10-13 December 2011. Conference Publication 2011;118:18.

59 Alessandrino EP, Della Porta MG, Bacigalupo A, Malcovati L, Angelucci E, Van Lint MT, Falda M, Onida F, Bernardi M, Guidi S, Lucarelli B, Rambaldi A, Cerretti R, Marenco P, Pioltelli P, Pascutto C, Oneto R, Pirolini L, Fanin R, Bosi A: Prognostic impact of pretransplantation transfusion history and secondary iron overload in patients with myelodysplastic syndrome undergoing allogeneic stem cell transplantation: a GITMO study. Haematologica 2010;95:476-484.

60 Arnan M, Pareja L, Sanchez-Ortega I, Alonso E, de Sevilla AF, Ribes J, Duarte RF: 81 Independent impact of transfusion dependency on overall survival and standardized mortality ratio of elderly patients with myelodysplastic syndromes. Leuk Res 2011;35:S31.

61 Aman M, Pomares H, Esteban L, Alonso E, Pareja L, S+ínchez-Ortega I, de Sevilla AF, Ribes J, Duarte RF: P-261 Mortality burden of transfusion dependency and iron overload in patients with myelodysplastic syndromes. Leuk Res 2013;37:S140.

62 Kadia TM, Garcia-Manero G, Kantarjian H, Pemmaraju N, Stein K, Teng A, Cortes JE: Retrospective analysis of effects of transfusion status on response to decitabine and survival in patients with myelodysplastic syndromes. Journal of Clinical Oncology Conference of the 2011 Annual Meeting of the American Society of Clinical Oncology, Chicago, 3-7 June 2011. Conference Publication 2011;29:20.

63 Thol F, Friesen I, Damm F, Yun H, Weissinger EM, Krauter J, Wagner K, Chaturvedi A, Sharma A, Wichmann M, Gohring G, Schumann C, Bug G, Ottmann O, Hofmann WK, Schlegelberger B, Heuser M, Ganser A: Prognostic significance of ASXL1 mutations in patients with myelodysplastic syndromes. J Clin Oncol 2011;29:2499-2506.
64 Sanz G, Nomdedeu B, Such E, Bernal T, Belkaid M, Ardanaz MT, Marco V, Pedro C, Ramos F, del Canizo MC, Luno E, Cobo F, Carbonell F, Gomez V, Munoz JA, Amigo ML, Bailen A, Bonanad S, Tormo M, Andreu R, Arrizabalaga B, Arilla MJ, Bueno J, Requena MJ, Bargay J, Sanchez J, Senent L, Arenillas L, de Paz R, Xicoy B, Duarte R, Cervera J: Independent impact of iron overload and transfusion dependency on survival and leukemic evolution in patients with myelodysplastic syndrome. Blood 2008; 112 : 238-239.

65 Savic A, Cemerikic-Martinovic V, Dovat S, Rajic N, Urosevic I, Sekulic B, Kvrgic V, Popovic $S$ : Angiogenesis and survival in patients with myelodysplastic syndrome. Pathol Oncol Res 2012;18:681-690.

66 Li V, Liang YS, Chu R, Sum HK, Chan FHY, Lau TKH, Kho BCS, Liu HSY, Chan JCW: Myelodysplastic Syndrome in Chinese $\mathrm{Pa}$ tients. 13th Congress of the EHA, Copenhagen, 2008.

67 Chee CE, Steensma DP, Wu W, Hanson CA, Tefferi A: Neither serum ferritin nor the number of red blood cell transfusions affect overall survival in refractory anemia with ringed sideroblasts. Am J Hematol 2008;83:611-613.

68 de Swart L, Smith A, Fenaux P, Bowen D, Sanz G, Hellstrom-Lindberg E, Symeonidis A, Cermak J, Germing U, Stauder R, Georgescu O, MacKenzie M, Malcovati L, Holm MS, Park S, Beyne-Rauzy O, Droste J, De Witte T: Transfusion-dependency is the most important prognostic factor for survival in 1000 newly diagnosed MDS patients with low- and intermediate-1 risk MDS in the European LeukemiaNet MDS registry. Blood Conference of the 53rd Annual Meeting of the American Society of Hematology, San Diego, 10-13 December 2011. Conference Publication 2011;118:18.

69 Kelaidi C, Beyne-Rauzy O, Braun T, Sapena R, Cougoul P, Ades L, Pillard F, Lamberto C, Charniot JC, Guerci A, Choufi B, Stamatoullas A, Slama B, De Renzis B, Ame S, Damaj G, Boyer F, Chaury MP, Legros L, Cheze S, Testu A, Gyan E, Bene MC, Rose C, Dreyfus F, Fenaux $P$ : High response rate and improved exercise capacity and quality of life with a new regimen of darbepoetin alpha with or without filgrastim in lower-risk myelodysplastic syndromes: a phase II study by the GFM. Ann Hematol 2013;92:621-631, erratum in Ann Hematol 2013;92:633.

70 Patnaik MM, Lasho TL, Finke CM, Gangat N, Caramazza D, Holtan SG, Pardanani A, Knudson RA, Ketterling RP, Chen D, Hoyer JD, Hanson CA, Tefferi A: WHO-defined 'myelodysplastic syndrome with isolated $\operatorname{del}(5 q)$ ' in 88 consecutive patients: survival data, leukemic transformation rates and prevalence of JAK2, MPL and IDH mutations. Leukemia 2010;24:1283-1289. 
71 Itzykson R, Thepot S, Quesnel B, Dreyfus F, Beyne-Rauzy O, Turlure P, Recher C, Dartigeas C, Vey N, Legros L, Delaunay J, Salanoubat C, Visanica S, Stamatoullas A, Isnard F, Marfaing-Koka A, de Botton S, Chelgoum Y, Taksin A-L, Plantier I, Ame S, Boehrer S, Gardin C, Beach CL, Ades L, Fenaux P: A prognostic score for overall survival (OS) with azacitidine (AZA) in higher risk MDS based on 282 patients (pts), and validated in 175 pts from the AZA 001 trial. Blood Conference of the 52nd Annual Meeting of the American Society of Hematology, Orlando, 4-7 December 2010. Conference Publication 2010;116: 19.

72 Fenaux P, Giagounidis A, List AF, Nimer SD, Hellstrom-Lindberg E, Powell BL, Yu X, Skikne B, Shammo JM, Del CC: Outcomes for patients (Pts) with low-/int-1-risk myelodysplastic syndromes (MDS) with del5q aged $<65$ years treated with lenalidomide (LEN) in MDS-003 and MDS-004: a retrospective combined analysis. Blood Conference of the 53rd Annual Meeting of the American Society of Hematology, San Diego, 10-13 December 2011. Conference Publication 2011;118:18.

73 Giagounidis AA, Kulasekararaj A, Germing U, Radkowski R, Haase S, Petersen P, Gohring G, Busche G, Aul C, Mufti GJ, Platzbecker U: Long-term transfusion independence in del(5q) MDS patients who discontinue lenalidomide. Leukemia 2012;26:855-858.

74 Sanchez-Garcia J, del Canizo C, Lorenzo I, Nomdedeu B, Luno E, de Paz R, Xicoy B, Valcarel D, Brunet S, Marco-Betes V, Garcia-Pintos M, Osorio S, Tormo M, Bailen A, Cerveroi C, Ramos F, Diez-Campelo M, Such E, Arrizabalaga B, Azaceta G, Bargay J, Arilla M-J, Falantes JF, Serrano-Lopez J, Sanz GF; Spanish Group on Myelodysplastic Syndromes: Multivariate time-dependent comparison of the impact of lenalidomide in lower-risk myelodysplastic syndromes with chromosome 5q deletion. Br J Haematol 2014;166:189-201.

75 Delforge M, Selleslag D, Beguin Y, Triffet A, Mineur P, Theunissen K, Graux C, Trullemans F, Boulet D, Van Eygen K, Noens L, Van Steenweghen S, Lemmens J, Pierre P, D'hondt R, Ferrant A, Deeren D, Van De Velde A, Wynendaele W, Andre M, De Bock R, Efira A, Breems D, Deweweire A, Geldhof K, Pluymers W, Harrington A, MacDonald K, Abraham I, Ravoet C: Adequate iron chelation therapy for at least six months improves survival in transfusion-dependent patients with lower risk myelodysplastic syndromes. Leuk Res 2014; 38:557-563.

76 Musto P, Villani O, Martorelli MC, Pietrantuono G, Guariglia R, Mansueto G, D'Auria F, Grieco V, Bianchino G, Sparano A, Zonno A, Lerose R, Sanpaolo G, Falcone A: Response to recombinant erythropoietin alpha, without the adjunct of granulocyte-colony stimulating factor, is associated with a longer survival in patients with transfusion-dependent myelodysplastic syndromes. Leuk Res 2010;34: 981-985.
77 Musto P, Pietrantuono G, Guariglia R, Villani O, D'Auria F, Falcone A, Sanpaolo G, Zonno A: Recombinant erythropoietin for transfusion-dependent myelodysplastic syndromes: long-term follow-up shows no modification of the natural history of treated patients and suggests a possible better prognosis for responders. Leuk Res 2007;31:S112-S113.

78 Rose C, Brechignac S, Vassilief D, Pascal L, Stamatoullas A, Guerci A, Larbaa D, Dreyfus F, Beyne-Rauzy O, Chaury MP, Roy L, Cheze S, Morel P, Fenaux P; Groupe Francophone des Myelodysplasies: Does iron chelation therapy improve survival in regularly transfused lower risk MDS patients? A multicenter study by the GFM. Leuk Res 2010;34:864870.

79 Kuendgen A, Lauseker M, List AF, Fenaux P, Giagounidis AA, Brandenburg NA, Backstrom J, Glasmacher A, Hasford J, Germing $\mathrm{U}$; International Working Group on MDS with $\operatorname{del}(5 q)$ : Lenalidomide does not increase AML progression risk in RBC transfusiondependent patients with low- or intermediate-1-risk MDS with del(5q): a comparative analysis. Leukemia 2013;27:1072-1079.

80 Alessandrino EP, Della Porta MG, Bacigalupo A, Van Lint MT, Falda M, Onida F, Bernardi M, Iori AP, Rambaldi A, Cerretti R, Marenco P, Pioltelli P, Malcovati L, Pascutto C, Oneto R, Fanin R, Bosi A: WHO classification and WPSS predict posttransplantation outcome in patients with myelodysplastic syndrome: a study from the Gruppo Italiano Trapianto di Midollo Osseo (GITMO). Blood 2008;112: 895-902.

81 Della Porta MG, Malcovati L, Boveri E, Travaglino E, Pietra D, Pascutto C, Passamonti F, Invernizzi R, Castello A, Magrini U, Lazzarino M, Cazzola M: Clinical relevance of bone marrow fibrosis and CD34-positive cell clusters in primary myelodysplastic syndromes. J Clin Oncol 2009;27:754-762.

82 Malcovati L, Della Porta MG, Cazzola M: Predicting survival and leukemic evolution in patients with myelodysplastic syndrome. Haematologica 2006;91:1588-1590.

83 Malcovati L, Porta MG, Pascutto C, Invernizzi R, Boni M, Travaglino E, Passamonti F, Arcaini L, Maffioli M, Bernasconi P, Lazzarino M, Cazzola M: Prognostic factors and life expectancy in myelodysplastic syndromes classified according to WHO criteria: a basis for clinical decision making. J Clin Oncol 2005; 23:7594-7603.

84 Malcovati L, Della Porta MG, Pascutto C, Invernizzi R, Passamonti F, Arcaini L, Maffioli M, Rumi E, Travaglino E, Bernasconi P, Lazzarino M, Cazzola M: The effect of transfusion dependency and secondary iron overload on survival of patients with myelodysplastic syndrome. Blood 2005;106:233A-234A.
85 Malcovati L, Germing U, Kuendgen A, Della Porta M, Invernizzi R, Giagounadis A, Hildebrandt B, Bernasconi P, Knipp S, Lazzarino M, Strupp C, Cazzola M: A WHO classificationbased prognostic scoring system (WPSS) for predicting survival in myelodysplastic syndromes (abstract 788). Blood 2005;106:233a.

86 Komrokji RS, Corrales-Yepez M, Al AN, Kharfan-Dabaja M, Padron E, Fields T, Lancet JE, List AF: Validation of the MD Anderson Prognostic Risk Model for patients with myelodysplastic syndrome. Cancer 2012;118: 2659-2664.

87 Patnaik MM, Hanson CA, Hodnefield JM, Lasho TL, Finke C, Knudson RA, Ketterling RP, Pardanani A, Tefferi A: Differential prognostic effect of IDH1 versus IDH2 mutations in myelodysplastic syndromes: a Mayo Clinic study of 277 patients. Blood Conference of the 53rd Annual Meeting of the American Society of Hematology, San Diego, 10-13 December 2011. Conference Publication 2011;118:18.

88 Patnaik MM, Lasho TL, Hodnefield JM, Knudson RA, Ketterling RP, Al-Kali A, Garcia-Manero G, Steensma DP, Pardanani A, Hanson CA, Tefferi A: SF3B1 mutations are prevalent in myelodysplastic syndromes with ring sideroblasts but do not hold independent prognostic value. Blood Conference of the 53rd Annual Meeting of the American Society of Hematology, San Diego, 10-13 December 2011. Conference Publication 2011;118:18.

89 Platzbecker U, Germing U, Stumpf J, Kroger N, Bohm A, Valent P, Schwerdtfeger R, Krieger O, Kobbe G, Ehninger G, Bornhauser M: The impact of transfusion-dependency on the outcome of patients with myelodysplastic syndromes (MDS) receiving allogeneic peripheral blood stem cell transplantation after myeloablative conditioning. Blood 2007;110:439A.

90 Platzbecker U, Germing U, Stumpf J, Scott B, Kroger N, Schwerdtfeger R, Valent P, Boehm A, Kobbe G, Ehninger G, Bornhauser M, Deeg H: The impact of transfusion-dependency on the outcome of patients with de novo myelodysplastic syndromes receiving allogeneic peripheral blood stem cell transplantation after myeloablative conditioning. Bone Marrow Transplant 2008;41:S212.

91 Thol F, Weissinger EM, Krauter J, Wagner K, Damm F, Wichmann M, Gohring G, Schumann C, Bug G, Ottmann O, Hofmann WK, Schlegelberger B, Ganser A, Heuser M: IDH1 mutations in patients with myelodysplastic syndromes are associated with an unfavorable prognosis. Haematologica 2010;95: 1668-1674.

92 Thol F, Yun H, Sonntag AK, Damm F, Weissinger EM, Krauter J, Wagner K, Morgan M, Wichmann M, Gohring G, Bug G, Ottmann O, Hofmann WK, Schambach A, Schlegelberger B, Haferlach T, Bowen D, Mills K, Ganser A, Heuser M: Prognostic significance of combined MN1, ERG, BAALC, and EVI1 (MEBE) expression in patients with myelodysplastic syndromes. Ann Hematol 2012;91: 1221-1233.
Transfusion Independence and OS in Patients with MDS
Acta Haematol 2016;136:23-42 DOI: $10.1159 / 000445163$ 
93 Cermak J, Kacirkova P, Mikulenkova D, Michalova K: A prognostic impact of transfusion dependency on survival of patients with early myelodysplastic syndrome. Blood Rev 2007; 21:S78.

94 Cermak J, Kacirkova P, Mikulenkova D, Michalova K: P105 The number of red blood cell transfusions is a significant but not an independent factor affecting survival in early MDS patients. Leuk Res 2007;31:S96-S97.

95 Cermak J, Mikulenkova D, Kacirkova P, Michalova K: Modification of WPSS for the time of diagnosis retains its prognostic impact and confirms transfusion dependency as an important parameter affecting survival in early MDS Patients with isolated erythroid dysplasia. Blood 2008;112:584.

96 de Swart L, Smith A, Fenaux P, Sanz G, Hellstrom-Lindberg E, Symeonidis A, Cermak J, Germing U, Stauder R, Georgescu O, MacKenzie M, Malcovati L, Holm MS, Madry K, Park S, Beyne-Rauzy O, Droste J, Bowen D, De Witte T: Early mortality in 1000 newly diagnosed MDS patients with low-and intermediate-1-risk MDS in the European LeukemiaNet MDS (EUMDS) registry. Blood Conference of the 54th Annual Meeting of the American Society of Hematology, Atlanta, 8-11 December 2012. Conference Publication 2012;120:16.
97 De Swart L, Smith A, Fenaux P, Symeonidis A, Hellstrom-Lindberg E, Sanz G, Cermak J, Georgescu O, Germing U, MacKenzie M, Beyne-Rauzy O, Malcovati L, Stauder R, Droste J, Bowen D, De Witte T: Disease-management of low- and intermediate-1 risk myelodysplastic syndromes: report on 800 newly diagnosed MDS patients from the European LeukemiaNet MDS registry. Blood Conference of the 52nd Annual Meeting of the American Society of Hematology, Orlando, 4-7 December 2010. Conference Publication 2010;116:19.

98 Falantes JF, Calderon C, Espigado I, Alonso D, Noya AM, Carrillo E, Martino ML, Montero I, Gonzalez J, Perez-Simon JA: Prognostic factors for survival and progression to acute myeloid leukemia in patients with lower-risk myelodysplastic syndromes. A new scoring system. Blood Conference of the 53rd Annual Meeting of the American Society of Hematology, San Diego, 10-13 December 2011. Conference Publication 2011;118:18.
99 Giagounidis A, Mufti GJ, Mittelman M, Sanz G, Platzbecker U, Muus P, Selleslag D, Beyne-Rauzy O, Te BP, Del CC, GuerciBresler A, Lubbert M, Quesnel B, Ganser A, Bowen D, Schlegelberger B, Fu T, Benettaib B, Hellstrom-Lindberg E, Fenaux P: Outcomes in RBC transfusion-dependent patients (PTS) with low-/intermediate (INT)1-risk myelodysplastic syndromes (MDS) with isolated deletion $5 \mathrm{Q}$ treated with lenalidomide (LEN): a subset analysis from the MDS-004 study. Blood Conference of the 55th Annual Meeting of the American Society of Hematology, New Orleans, 7-10 December 2013. Conference Publication 2013;122:21.

100 Seymour JF, Santini V, Fenaux P, Giagounidis AAN, Sanz GF, Finelli C, Lucy LM, Backstrom J, Beach CL: Achievement of red blood cell (RBC) transfusion independence with azacitidine (AZA) leads to improved survival in patients with higher-risk myelodysplasias regardless of baseline transfusion needs. Blood 2010;116:773-774. 